MRJIAM

11,2

178

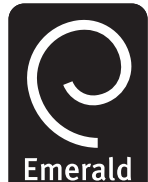

Management Research: The Journal of the Iberoamerican Academy of Management

Vol. 11 No. 2, 2013

pp. 178-212

(C) Emerald Group Publishing Limited 1536-5433

DOI 10.1108/MRJIAM-Dec-2011-0465

\section{The usefulness of financial reporting for internal decision-making in Portuguese municipalities}

\author{
Sónia Paula S. Nogueira \\ Departamento de Ciências Empresariais e Juridicas, \\ Instituto Politécnico de Bragança, Mirandela, Portugal \\ Susana Margarida F. Jorge \\ NEAPP - Núcleo de Estudos em Administração e Politicas Públicas, \\ Universidade do Minho, Braga, Portugal and \\ Faculdade de Economia, Universidade de Coimbra, Coimbra, Portugal, and \\ Mercedes Cervera Oliver \\ Departamento de Contabilidad, Universidad Autónoma de Madrid, \\ Madrid, Spain
}

\begin{abstract}
Purpose - The article aims to analyse the perception of the internal users regarding the usefulness of the municipal financial reporting in the context of decision making in the Portuguese local administration.

Design/methodology/approach - This research is quantitative and positive, based on a cross-section analysis through the online application of a questionnaire to the decision makers (politicians and technicians) of the 308 Portuguese municipalities. The approach is based on the paradigm of information usefulness.

Findings - The results indicate a high usefulness for the decision making of the municipal financial reporting, in its current form and content. However, this usefulness would increase if information, other than what is mandatory, were introduced. In general, the two different groups of decision makers, politicians and technicians, behave somewhat differently, regarding the usefulness that the financial reporting holds for them. The technical decision makers consider it of greater value. There is no statistical evidence that shows that there is a link between the training area and professional experience of the internal decision makers and the usefulness of the municipal financial reporting. Both types of users show a preference for the information set within the budgetary accounts, although accrual-based information also proves to be of excellent value. Research limitations/implications - The main limitations of this study are related to the way information was collected (questionnaire) to obtain empirical evidence. The questionnaire, sent by email, despite reaching a wide-ranging and dispersed population, does not assess the truthfulness and integrity of the responses. Furthermore, it does not make it possible to really identify the usefulness of the municipal financial reporting. The use of perceptive measures can also represent a threat to the study's internal validity. Practical implications - The results of this study have important repercussions on the internal decision makers concerning the usefulness of the municipal financial reporting. Particularly, since the general approach towards the usefulness of the reporting could become a solid work basis for the regulatory bodies to enhance the current reporting model in the light of its suitability within the internal decision making.

Originality/value - Research on this study is original as it provides, as far as the authors are aware, the first empirical evidence of the perceptions of internal users on the usefulness of the municipal financial reporting in Portugal, in regard to decision making.
\end{abstract}

Keywords Municipal financial reporting, Local government accounting, Usefulness,

Internal decision making, Decision making, Financial reporting, Portugal

Paper type Research paper 


\section{Resumen}

Objetivo - Este trabajo persigue analizar las percepciones de los usuarios internos con respecto a la utilidad de la información financiera en el contexto de la toma de decisiones municipales, concretamente en la Administración Local portuguesa.

Diseño/metodología/enfoque - Se trata de una investigación positivista y cuantitativa, basada en el análisis cross-section a través de la aplicación online de un cuestionario dirigido a los tomadores de decisiones (técnicos y políticos) de 308 municipios portugueses. El enfoque utilizado se fundamenta en el paradigma de utilidad de la información.

Resultados - Los resultados muestran que el modelo de rendición de cuentas municipal, en su forma y contenido actuales, es de gran utilidad para la toma de decisiones. Sin embargo, esta utilidad aumentaría con la introducción de información adicional a la que actualmente se requiere divulgar. En general, los dos grandes grupos de decisores, políticos y técnicos, presentan un comportamiento ligeramente diferente con respecto a la utilidad atribuida a la información contenida en los estados financieros obligatorios. El grupo de decisores técnicos le asigna mayor utilidad. No se han encontrado evidencias estadísticas que permitan afirmar que la formación y la experiencia profesional de los decisores internos se encuentran relacionadas con la utilidad otorgada a la información contenida en las cuentas anuales municipales. Se ha constatado una preferencia, por ambos tipos de usuarios, por la información preparada según la contabilidad presupuestaria en base de caja, mientras que la información elaborada de acuerdo con el principio de devengo revela tener mayor utilidad.

Limitaciones de la investigación - Las principales limitaciones de este estudio están relacionadas con el cuestionario empleado, la técnica de recolección de datos seguida, para obtener la evidencia empírica. Las respuestas al cuestionario se han conseguido por medio del correo electrónico. Tal consideración posibilita alcanzar una población amplia y dispersa, pero no permite evaluar ni la honestidad y la integridad de las contestaciones, ni evaluar el conocimiento real de la utilidad de la información emitida por el modelo de rendición de cuentas municipal por parte de los encuestados. El uso de medidas de opinión también puede constituir una amenaza à la validez interna del estudio.

Implicaciones prácticas - Los resultados de este estudio pueden tener importantes implicaciones para los tomadores de decisiones internos sobre la utilidad de la información contenida en el modelo de rendición de cuentas municipal. En particular, dependiendo de la utilidad que el modelo de rendición ofrece a sus usuarios y de las necesidades de información de éstos, este trabajo puede proporcionar una base sólida de trabajo para que los órganos reguladores ajusten el actual modelo de rendición de cuentas con vista a que este modelo se modifique para que sea más adecuado para la toma de decisiones internas.

Originalidad/valor - La originalidad de esta investigación estriba en que parece constituir la primera evidencia empírica de la percepción de los usuarios internos sobre la utilidad de la información del modelo de rendición de cuentas municipal en Portugal, en el contexto de la toma de decisiones.

Palabras clave Informes financieros municipales, Contabilidad de los gobiernos locales, Utilidad, Toma de decisiones interna

Tipo de artículo Artículo de investigación

\section{Resumo}

Objetivo - $\mathrm{O}$ artigo analisa as perceções dos utilizadores internos quanto à utilidade do relato financeiro municipal no contexto das tomadas de decisão, na Administração Local portuguesa.

Desenho/metodologia/abordagem - Trata-se de uma investigação quantitativa e positivista, baseada numa análise cross-section através da aplicação online de um questionário aos tomadores de decisões (técnicos e políticos) dos 308 municípios Portugueses. A abordagem utilizada assenta no paradigma da utilidade da informação.

Resultados - Os resultados mostram uma utilidade elevada para as tomadas de decisão do relato financeiro municipal, na sua forma e conteúdo atuais. Porém, esta utilidade aumentaria com a introdução de outra informação para além da que atualmente é de divulgação obrigatória. Em geral, os dois grupos de diferentes decisores - políticos e técnicos - apresentam um comportamento ligeiramente diferente no que respeita à utilidade atribuída ao relato financeiro, sendo que o grupo de decisores técnicos atribui

\section{The usefulness of financial reporting}

179 
MRJIAM 11,2

180

maior utilidade. Não se encontraram evidências estatísticas que permitam afirmar que a área de formação e a experiência profissional dos decisores internos se encontre relacionada com a utilidade atribuída ao relato financeiro municipal. Constata-se uma preferência, de ambos os tipos de utilizadores, pela informação preparada no âmbito da contabilidade orçamental em base de caixa, embora a informação preparada de acordo com o regime de acréscimo revele ter também utilidade elevada.

Limitações da investigação - As principais limitações deste estudo relacionam-se com a utilização da técnica de recolha de dados (questionário) para a obtenção de evidência empírica. A aplicação do questionário, aqui por correio eletrónico, se permite atingir uma população vasta e dispersa, não permite avaliar a honestidade e integridade das respostas, além de também não permitir efetuar uma avaliação do conhecimento real da utilidade do relato financeiro municipal. O uso de medidas percetivas pode também ser uma ameaça à validade interna do estudo.

Implicações práticas - Os resultados deste estudo têm implicações importantes para os decisores internos em relação à utilidade do relato financeiro municipal. Em particular, a abordagem geral à utilidade do relato pode constituir uma forte base de trabalho para os órgãos reguladores aperfeiçoarem o atual modelo de relato em função da adequabilidade deste para as tomadas de decisão internas.

Originalidade/valor - A investigação neste trabalho é original na medida em que proporciona, a nosso conhecimento, a primeira evidência empírica das perceções dos utilizadores internos sobre a utilidade do relato financeiro municipal em Portugal, no contexto das tomadas de decisão.

Palavras-chave Relato financeiro municipal, Contabilidade Autárquica, Utilidade, Tomadas de decisão internas

Tipo de artigo Artigo de investigação

\section{Introduction}

During the past decades, many countries have undertaken significant reforms in public accounting and, therefore, in the financial reporting of information by public entities. The new accounting systems responded not only to the legitimacy, lawfulness and compliance with regulations, through budgetary cash-based information, but also to the availability of information concerning the efficient use and supply of public resources. Among other guidelines, the accounting information system in the public sector has been directed at the dissemination of useful and suitable information, allowing its users to assess and make decisions in a more rational and logical way (Chan, 2003; Lee, 2008; Hookana, 2008). The reforms introduced in public sector accounting aim at improving the financial reporting for the decision makers and for accountability purposes in general.

The new developments in public management and accounting were also felt in the Portuguese accounting system, including local administration. The overall reform process in the accounting system of the public sector took its first steps in Portugal in the 1990s, with what became known as the Reform of State Financial Administration. Following this reform agenda, the Official Local Government Accounting Plan (Plano Oficial de Contabilidade das Autarquias Locais (POCAL)) was approved in 1999, which embodied the starting point for the local administration management of new instruments helpful in the decision-making process.

Ten years on since the publication of the POCAL, the adoption of the accounting system under this legislative framework, whose main purpose is to support management, has not been empirically studied yet, namely in respect to the usefulness of financial reporting produced for decision making. Despite the theoretical intentions set in the new local government accounting system, one might question whether the current reporting model of financial reporting is actually adequate to reality, particularly whether the financial reporting prepared and disseminated in the scope of POCAL by Portuguese municipalities is, in fact, useful for decision making. 
It is under this framework that this study is developed, aiming at analysing the users' perceptions concerning the usefulness of the municipal financial reporting within internal decision making. More specifically, this study intends to answer the following questions:

$R Q 1$. Which accounting statements are more useful for internal decision making?

$R Q 2$. What is the use of information organised according to the accrual basis for internal decision making?

RQ3. What type of non-mandatory organised information is revealed as useful for internal decision making?

$R Q 4$. What is the relationship between the respondents and the usefulness they attributed to municipal financial reporting?

Internal users were empirically considered since they have undertaken a leading role in the use of financial reporting by local government accounting, with the introduction of the new public management (NPM) principles. Following the particular emphasis on decision making and on accountability on the part of executives, internal users were considered one of the main users of financial reporting regarding decision making, together with external users who use it predominantly for accountability.

As in other studies (Brusca, 1997; Mack, 2004; Mack and Ryan, 2006; Cohen et al., 2007; Cohen, 2009; Kober et al., 2010; Andriani et al., 2010), the quantitative and positive approach based on a cross-section analysis was assumed to be the most adequate, taking into account the source of necessary information and the expectations about the most satisfactory method in obtaining that piece of information.

The present study is structured into four sections, including this introduction. The Sections 2 and 3 focus on the review of research that begins with an approach to the NPM and to the new financial information needs, in accordance with the public accounting reforms and referring in particular to the Portuguese context; further on, studies on the usefulness of financial reporting in government entities are mentioned. In the Section 4, the empirical study is carried out, describing and defining the objectives and the research questions, the methodology, the hypotheses, the information collection instrument, the population, the method of collecting the information, and the sample. The last two points of this section combine the results through a descriptive analysis and then through the hypotheses tests. Lastly, some conclusions, as well as some constraints to the study, are presented.

\section{NPM, information needs and public accounting reforms}

During the last three decades, wide-ranging reforms in the public sector of several countries have been carried out inspired by the NPM concepts. The NPM concentrates on reducing the differences between the public and private sectors, aligning management practices (Hood, 1995; Lapsley, 2009) and highlighting the accountability process in the public sector to take greater responsibility for outcomes and results (Hood, 1995). The growing need felt by the governments to improve the external and internal accountability process to the legislative bodies and citizens in general (Chan, 2003; Lee, 2008; Christiaens and Rommel, 2008; Hookana, 2008), mainly in the modern democracies and market economies, steered the development of a new accounting information system in the public sector able to provide more adequate information for decision making.

\section{The usefulness of financial reporting}

181 
MRJIAM 11,2

182
Within the scope of public accounting, the NPM movement had deep effects on the accounting practices (Hood, 1991, 1995). Focusing on accounting's key role, NPM calls for a reform model that gives preference to measurements and to results (Olson et al., 1998; Lapsley, 1999, 2009; Hyndman and Connolly, 2011). As the traditional accountability process prevailing until then in the public sector, financial and legal accountability, revealed itself to be inadequate to measure the ruling entities, governing bodies and public managers, a new accountability arose, named management accountability (Guthrie, 1998; Mack, 2004). Moreover, the growing autonomy of public sector leaders regarding decision making demanded another type of information, besides the information prepared on a cash basis. The budgetary cash-based accounting system was, therefore, considered insufficient to keep up with the change in the management information needs, namely by describing inaccurately the economic and financial situation of public organisations, and by not enabling adequate and useful information in the control process, in planning and in performance assessment (Lapsley, 1999; Cohen, 2007).

Given the changes which have since occurred in public management, the accounting systems of public administration entities were unable to meet the current demands for information, setting new objectives that led to a change in the conceptual and methodological structure. New accounting instruments were hence introduced in the public sector, namely the accrual basis in the outset of financial statements, complementing the traditional cash basis control and commitments.

International literature signposts that the introduction of the accrual accounting information systems represents one of the most important guidelines in the public accounting reform in the last decades (Pallot, 1997; Brorström, 1998; Guthrie, 1998; Brusca and Condor, 2002; IFAC-PSC, 2002; Chan, 2003; Pina and Torres, 2003; Van der Hoek, 2005; Anessi-Pessina and Steccolini, 2007; FEE, 2007; Montesinos and Brusca, 2009; Pina et al., 2009; Hyndman and Connolly, 2011). According to this literature, among the key attributes of the new product, highlighting goes to the main positive aspects resulting from the implementation of accrual accounting, explicitly: useful information made available for the decision making and the provision of additional information that enhances transparency, provision of responsibilities and the assessment of the public entities' performance to the benefit of the users.

However, several authors have been questioning the use of the accrual accounting in the public sector, not only because of both of the theoretical and practical aspects, but also due to its consequences (Montesinos et al., 1995; Guthrie, 1998; Brorström, 1998; Christiaens, 1999; Guthrie et al., 1999; Hodges and Mellett, 2003; Wynne, 2008; Christiaens and Rommel, 2008; Lapsley, 2009; Hyndman and Connolly, 2011). The particular nature of public entities and the heterogeneity of their activities represent the most common reasons.

The study of accrual-based information is controversial and discussed in numerous international researches, namely its usefulness for decision making. Several authors, for instance Ouda (2007) and Caba et al. (2009), consider the implementation of the accrual accounting and, therefore, the execution of the International Public Sector Accounting Standards - IPSASs - a radical innovation to the public accounting systems that will allow, among other aspects, the development of the accounting information system towards a greater usefulness.

The public accounting reform has been, thus, grounded on the change of an accounting system which provides little information towards a system that discloses 
more adequate and wide-reaching information over the public resources management, catering for an improved economic and financial control on the government activities. This approach seeks to provide a more informative and useful accounting for decision making and responsibilities (Lüder, 1992). This accounts for progress in public accounting regarding the usefulness paradigm, providing more complete information about the assets, liabilities, income, expenses, property and change (Ouda, 2007), aiming at the most accurate image at the management level (Lüder, 1992).

At the international level, the professional organisations' guidelines (e.g. Governmental Accounting Standards Board - (GASB) - and International Public Sector Accounting Standards Board - (IPSASB)) have encouraged the public accounting reforms, e.g. on the implementation of the accrual accounting and on the improvement of reporting of financial information of the public sector entities, with the purpose of promoting timely and useful information for decision making and control (Lapsley, 1999; Cohen, 2007). According to the Conceptual Framework Exposure Draft 1 of IPSASB (2010), the goal of the financial reporting of the public sector entities is: "to provide useful information to the users, whether for accountability purposes or for supporting decisions regarding allocation of resources, political and social decisions." (IPSASB: CF-ED 1, 2010, §1.10).

In this changing context, within the NPM and following the example of several countries, reforms have been carried out in the Portuguese public sector's accounting systems over recent years. These reforms devised, among others, a new model for a more wide-reaching and informative financial reporting. With particular reference to the Portuguese local administration, legislation was approved to respond to the current needs of the users of financial reporting (e.g. the needs of the municipal bodies' management). The Law of Public Accounting[1] launched the most recent reform to the Portuguese public accounting, subsequently regulated by the setting of basic conditions for its application[2]. However, the approval of the Official Public Accounting Plan embodies the most important stage of this reform (POCP - Plano Oficial de Contabilidade Pública)[3]. Such a plan ensures that the bodies of the central, regional and local administration use an integrated accounting system (budget, property and costs).

The local government accounting reform in Portugal resulted in the publication of the Official Local Government Accounting Plan in 1999[4], playing a crucial role in the preparation and disclosure of backup information for decision making and internal control by local government leaders.

More generally, with the approval of the POCAL, timely, useful and trustworthy information would be available to internal decision makers, among others, and would allow more control and transparency in the spending of public financial resources (increasingly depleted), to further maximise its efficiency, efficacy and economy. Additionally, the integration of the budgetary accounting with the financial and costs accountings meets the needs of improving the financial reporting of local government, crucial for decision making in the local government administration. The financial reporting within POCAL was consequently extended, displaying not only information on the economic, financial and patrimonial situation (accrual basis), but also on the budgetary situation (on a cash basis).

To summarize, changes to the management models within NPM caused new informative needs that devised, on a global scale, strong reforms on public accounting and on its financial reporting. Increasingly, public entities leaders need more useful
The usefulness of financial reporting

183 
MRJIAM

11,2

184 and timely information for the most adequate decision making. Therefore, the paradigm of information users and their needs plays a crucial role in explaining the innovations carried out in accounting systems and in financial reporting.

This usefulness approach is hence the central theoretical bedrock of this study and shall be taken into account in the empirical analysis on the usefulness of the financial reporting of Portuguese municipalities.

\section{The usefulness of financial reporting within the government entities: focus on local government}

According to international literature, work on the usefulness of financial reporting produced and released by the public entities is substantially reduced (Hay and Antonio, 1990; Daniels and Daniels, 1991; Collins et al., 1991; Brusca, 1997; Tayib et al., 1999; López and Caba, 2004). More specifically, literature focused on the usefulness of financial reporting for management purposes, including decision making and control within local government organisations, is particularly poor (Mack, 2004; Yamamoto, 2008; Windels and Christiaens, 2008; Grossi and Reichard, 2009; Cohen, 2009; Kober et al., 2010; Andriani et al., 2010).

After almost three decades of the NPM reforms, during which the public management model has been severely criticised, the new financial information still does not totally fulfil the needs of its users (Hay and Antonio, 1990; Daniels and Daniels, 1991; Brusca, 1997; Mack, 2004; Mack and Ryan, 2006). Some authors have studied the information needs released in the public entities' financial reporting, of both internal and external users (Robbins, 1984; Jones et al., 1985; Hay and Antonio, 1990; Daniels and Daniels, 1991; Collins et al., 1991; Crain and Bean, 1998; Priest et al., 1999; Mack and Ryan, 2006). After analysing the results, the authors conclude that, in a general way, the users have more budgetary cash-based information than accrual-based information. However, Kober et al. (2010), in a more recent study applied in the departments of the Australian Government, intending to analyse users' and trainers' perceptions of the usefulness of budgetary cash-based information and financial accrual-base information for decision making, found the results obtained were contrary to the ones found in previous studies. The respondents were:

- internal users (department's directors and vice-directors); and

- external users (government staff responsible for the provision of the financial reporting for the publication of the Ministry of Finance and Treasury's Budget, and members of the Public Accounts Committee).

The results indicate that the information organised on an accrual basis is generally considered more useful than the budgetary cash-based accounting, pointing to the conclusion that the former seems to have been increasing. Likewise, Andriani et al. (2010) prove the results obtained by Kober et al. (2010) for the same type of decisions, but within the context of the internal decisions and only in respect to the public management of the departments of the Australian Government.

From the studies focused on internal users, some do not make a distinction between politicians and managers or, in some cases, have only studied one of these users' categories, covering mainly the financial vs non-financial information. Furthermore, Olson and Shalin-Andersson (1998) and Guthrie et al. (1999) underline the reduced usefulness of the financial reporting by the majority of politicians. At the same time, 
Ter Bogt (2004) argues that politicians are unlikely to use performance measures and instead they trust informal communication. Jones et al. (1985) and Hay and Antonio (1990) also reveal that the budget results and the indicators of efficiency and effectiveness illustrate high usefulness, other than the information disclosed in the financial reporting.

Only a small number of studies takes into account the politicians' perspectives or compares them with the managers'. For instance, Brusca (1997), on the one hand, in a study on Spanish municipalities intended to determine the usefulness of the financial statements (of a budgetary, economic and financial nature), confirmed that politicians were the ones who gave less importance to financial reporting, due to insufficient training. On the contrary, managers were the users who attached more importance to financial reporting. On the other hand, the author realised that even though the financial reporting of the Spanish municipalities reveals itself to be useful for the financial directors, municipal bodies, the court of auditors and creditors, the information disclosed is not actually used to the greatest extent. Paulsson (2006), when analysing the introduction of accrual accounting by the Swedish Central Administration, has verified that the information on an accrual basis accounting is used more by managers than by politicians.

In the Portuguese context, to date and as far as we are aware, there are only two published studies on the internal usefulness of the financial information within the public sector - Barbosa (2006) and Carvalho et al. (2008). The latter focuses on the Portuguese local administration and the former, a study developed for a central hospital, concentrates on the health sector. Carvalho et al. (2008) analysed the internal usefulness of the Portuguese municipalities' financial information tabled in accountability. The authors concluded that both executive and deliberative bodies discuss the same types of budgetary cash-based accounting. Nevertheless, it is the executive body that attaches the greatest importance to the different types of economic and financial information, that is, on an accrual basis. The authors also stated that both bodies place higher emphasis on the budgetary information. It is important to stress that neither of these works analyses in detail the financial information for the several decisions among politicians and managers, nor examines the possible factors affecting that usefulness. For that reason, the current study is an attempt to contribute to filling this noteworthy gap.

\section{Empirical study}

\subsection{Objectives and research questions}

Even though the publication of POCAL, as referred to, has been the main aspect of the reform of local government accounting in Portugal, it is not certain that, in spite of theoretical intentions recommended in the diploma, the current model of financial reporting is duly adequate and that it makes available in reality, information that is useful for decision making (similar to what has been verified in other countries e.g. Brusca, 1997; Mack, 2004; Yamamoto, 2008). Thus, this empirical study has as the objectives, in the context of internal decision making (political and technical decision makers) in the Portuguese municipalities:

- to assess the usefulness of the municipal financial reporting, namely of the mandatory preparation documents;

- to verify the usefulness of the accrual-based information; and

- to identify and assess the usefulness of other information of voluntary preparation.

\section{The usefulness of financial reporting}

185 
MRJIAM

11,2

186

In addition, by performing a cross-section analysis, to evaluate if the profile of the respondent (according to the training area and professional experience) is, in some way, associated with the usefulness attributed to the municipal financial reporting. The proposed objectives intend to answer the following research questions:

$R Q 1$. Which accounting statements are more useful for internal decision making?

$R Q 2$. What is the use of information organised according to the accrual basis for internal decision making?

RQ3. What type of non-mandatory organised information reveals itself to be useful for internal decision making?

RQ4. What is the relationship between the respondents and the usefulness they attributed to municipal financial reporting?

\subsection{Research methodology}

In public sector accounting research, particularly in local government, the authors used both a quantitative approach (Robbins, 1984; Jones et al., 1985; Daniels and Daniels, 1991; Collins et al., 1991; Brusca, 1997; Crain and Bean, 1998; Tayib et al., 1999; Priest et al., 1999; López and Caba, 2004; Mack, 2004; Mack and Ryan, 2006, 2007; Yamamoto, 2008; Windels and Christiaens, 2008; Cohen, 2009; Kober et al., 2010; Andriani et al., 2010) and a qualitative approach (Hay and Antonio, 1990; Van Helden and Ter Bogt, 2001; Budding, 2004; Grossi and Reichard, 2009).

In both the quantitative and qualitative approaches, different research paradigms have been adopted, taking into account the criteria of the position of the researcher on the nature of the social sciences (objective or subjective) and the perspective that the researcher has on the reality (radical changes or regulation) (Hopper and Powell, 1985).

Specifically, the positivist paradigm research (Hopper and Powell, 1985; Davila and Oyon, 2008; Vieira, 2009) assumes the independence of the researcher before the reality. It utilizes the technique of formulation and verification of the hypotheses, normally using tools of quantitative character through the adoption of the methods of social sciences in order to find and deduce a causality association (Davila and Oyon, 2008). In this manner, it promotes the scientific construction through a perspective of acceptance and rejection of the hypotheses; in other words, it is a constant search for the truth (Davila and Oyon, 2008; Vieira, 2009; Lukka, 2010).

Because the evidence that is intended to be obtained is necessary to comply with the defined objectives and is compatible with an objective conception of the reality, seen as external to the researcher, it is understood that the most adequate option for this study is the quantitative approach with the use of the positive paradigm research.

\subsection{Research hypotheses}

Brusca (1997) and Yamamoto (2008) considered that the training area and professional experience of the users is related with the usefulness of the financial reporting, inasmuch as they make use for their decision making of different types of information according to some personal characteristics. For example, Brusca (1997) proved that the users who have training in the area of management attribute greater usefulness to the information disclosed in financial reporting. In the same way, Yamamoto (2008) verified that the training area and professional experience are positively related with 
the usefulness attributed to the financial statements. Along this line, and considering the possibility of a positive association between the training area and professional experience of the internal decision makers (politician and technicians) and the usefulness of municipal financial reporting for the process of decision making, the following research hypotheses were formulated:

H1. The area of training of political decision makers is directly related to the usefulness of municipal financial reporting.

H2. The area of training of technical decision makers is directly related to the usefulness of municipal financial reporting.

H3. The professional experience of political decision makers is directly related to the usefulness of municipal financial reporting.

H4. The professional experience of technical decision makers is directly related to the usefulness of municipal financial reporting.

One of the main changes verified in the recent reform of local government accounting in Portugal was, as explained, the introduction of the accrual basis in the accounting systems. For Guthrie (1998), Chan (2003), Van der Hoek (2005), Kober et al. (2010) and Andriani et al. (2010), the use of the accrual basis in the preparation of the financial reporting of public entities allows for disclosure of information of greater usefulness for decision making, namely internal decision, such as budget preparation and defining fees. This information helps to improve transparency and rendering of the responsibilities of the local entities benefiting the users (Kober et al., 2010). Some studies (Mack, 2004; Yamamoto, 2008; Carvalho et al., 2008; Grossi and Reichard, 2009) conclude that users of financial reporting do not recognize the accrual-based information useful for their decision making, and continue to show preference for the budgetary cash-based information. On the contrary, Kober et al. (2010) and Andriani et al. (2010), in a study performed to assess the perceptions of the users and preparers of the financial reporting regarding the usefulness of the accrual-based and budgetary cash-based information for internal decision making, reveal that the accrual-based information is generally considered of greater usefulness.

Based on early studies and considering the reality of the Portuguese municipalities, the following research hypothesis was formulated:

H5. The accrual-based information has low usefulness for internal users as support to the internal decision making.

\subsection{Data collection}

For the collection of data, a survey done by questionnaire was chosen[5] (Appendix), to essentially reach a large number of respondents and make it possible to verify the formulated hypotheses (Gillham, 2008; Ferreira and Sarmento, 2009).

Since this instrument has limitations, recommendations by various authors (Gillham, 2008; Ferreira and Sarmento, 2009) were considered. The questionnaire was tested during February via some of those people pertaining to the population to be studied, as well as academics, knowledgeable in the area of study and having ample experience in structuring and inducting research by using surveys.
The usefulness of financial reporting

187 
MRJIAM 11,2

188
A structured type of questionnaire was chosen (Gillham, 2008), similar to those of other authors (Daniels and Daniels, 1991; Collins et al., 1991; Brusca, 1997; Tayib et al., 1999; López and Caba, 2004; Mack, 2004; Mack and Ryan, 2006, 2007; Yamamoto, 2008; Windels and Christiaens, 2008; Cohen, 2009; Kober et al., 2010; Andriani et al., 2010). The elaboration of the questionnaire began by reviewing the literature on empirical studies (Section 3), with the systematization of the information by raising questions already developed and used in other studies. However, items that only concern financial reporting of the Portuguese municipalities were included, such as the case of the accounting statements according to the POCAL. In addition to the information on the respondents (position/function, professional experience - number of years at their positions/functions at the municipality, level of higher education, training area and age), the questionnaire was structured according to the objectives of the study, and the part being analysed here comprises only one dimension in respect to the usefulness of financial statements (also including the usefulness of the content of the principal statements - balance sheet and income statements by nature) of non-mandatory preparation and disclosure in the context of the POCAL and of other financial information, used in internal decision making, that are prepared and disclosed voluntarily. To evaluate the usefulness, ordinal variables were used based on the Likert rating scale of 5 points, similar to the studies of Tayib et al. (1999), Mack (2004), Yamamoto (2008), López and Caba (2004), Andriani et al. (2010) and Kober et al. (2010). For application of questionnaire, we opted to send it by email.

\subsection{Population, the process of collecting data and sampling}

Taking into account the defined objectives of this study and considering that the study is based on the analysis of the local Portuguese administration, all of the political (members of the executive body) and technical[6] decision makers, those mainly responsible for the finance area of all of the Portuguese municipalities (308), were defined as the target population.

The respondents were selected by taking into consideration their predominant role as internal municipal decision makers[7] and, subsequently, as the principal users of the municipal financial information[8].

Given the need to use electronic mail to collect the necessary data (sending out the questionnaire), a database was created with the necessary information of all the political and technical decision makers by looking up the information available on the webpage of the Local Government of the Directorate General of local entities and the webpage of Portuguese municipalities. In addition, follow-up emails were sent and phone calls made to the municipalities whose information had not been obtained. The total population is composed of 616 decision makers of the 308 Portuguese municipalities.

The survey was conducted between April and July 2011. During the entire process of collecting the data, practical questions from the respondents were clarified and their requests for assistance in accessing the survey were answered by telephone or email. "Reminders" to complete the questionnaire were sent out in May. By the end of this process, 302 completed questionnaires had been gathered, which correspond to 49.03 percent. The percentage of responses can be considered as very satisfactory when compared to those of other analogous studies[9].

The 302 received responses were from 231 municipalities (75 percent of the total), as only 71 were responses obtained from both groups of decision-makers. The 302 responses 
obtained are distributed as follows between the Portuguese municipalities in terms of geographic location by region: 103 decision makers of the municipalities of the North region (34.11 percent), 86 of the Central region (28.48 percent), 18 of Lisbon (5.96 percent), 50 of the Alentejo region (16.56 percent), 17 of the Algarve region (5.63 percent), 19 of the autonomous region of Açores (6.29 percent) and seven of the autonomous region of Madeira (2.98 percent).

In accordance with the results obtained, a greater availability on the part of the technical decision makers to answer the questionnaire was verified (67.53 percent), noting that globally an acceptable number of responses ( $>30$ percent) was received from both of the groups of internal decision makers.

In order to assess the representativeness of the sample, taking into account the totality of the 616 internal decision makers of the 308 Portuguese municipalities, two aspects were considered:

(1) The size of the sample which characterizes the quantitative representativeness; and

(2) The similarity of characteristics with the population of the study (size of the municipality in terms of numbers of inhabitants[10]), which characterizes the qualitative representativeness.

In terms of the quantitative representativeness assuming a level of significance of 5 percent and an error of approximately 5.64 percent, a size of the sample of 302 collected observations were obtained (49.03 percent of the population) which leads to the conclusion that the size of the sample is representative of the population. Thus, it can be affirmed that the respondents of the sample are representative of the population of the internal decision makers from Portuguese municipalities, which will be reverberated in terms of the generalization of the results.

In relation to the qualitative aspect, and based on the data obtained in Table I, the study tried to analyse the size of the respondent municipalities by the number of inhabitants, according to the methodology adopted by Carvalho et al. (2010)[11]. Considering the defined criteria and the results obtained, it is possible to notice that this study was better accepted by the respondents of the smaller municipalities ( 54.3 percent), the percentage of participation decreasing as the size of the municipality increases. Thus, the respondents belonging to the medium and large municipalities constitute 45.7 percent of the received responses. Given the configuration of municipalities in Portugal according to size, in terms of population and total number, it is also worth mentioning that the respondents belonging to the small municipalities represent more

\begin{tabular}{|c|c|c|c|c|}
\hline \multirow[b]{2}{*}{ Small } & \multicolumn{2}{|c|}{ Sample } & \multicolumn{2}{|c|}{ Population } \\
\hline & $\begin{array}{c}n \\
164\end{array}$ & $\begin{array}{c}\% \\
54.30\end{array}$ & $\begin{array}{c}n \\
360\end{array}$ & $\begin{array}{c}\% \\
58.44\end{array}$ \\
\hline Medium & 113 & 37.42 & 210 & 34.09 \\
\hline Large & 25 & 8.28 & 46 & 7.47 \\
\hline Total & 302 & 100.00 & 616 & 100.00 \\
\hline
\end{tabular}

Note: Representativeness of the sample
The usefulness of financial reporting

189

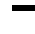


MRJIAM

11,2

190 than half of those to be surveyed. The large municipalities are represented in a lesser number in the sample, corresponding to 8.28 percent. Considering that the sample is probabilistic, the proximity of the percentages of the sizes of the sample with the percentages of the population (53.30 percent vs 58.44 percent; 37.42 percent vs 34.09 percent; 8.28 percent vs 7.47 percent) seems to reveal that, also from the qualitative point of view, the sample is representative of the population being analysed, to the extent that it includes a diversity of characteristics that portrays the totality of the population of the Portuguese municipalities.

In order to minimize differences in the responses between the respondent municipalities $(n=231)$ and the non-respondent municipalities $(n=77)$ in terms of size (according to the number of inhabitants) and region, the nonparametric, one-sample $\chi^{2}$ test was performed. The application of $\chi^{2}$ statistic intended to verify whether the distribution of the size and the geographic location by region of the respondent municipalities does not present differences in relation to the distribution of the same characteristics in the population. The results obtained indicate that there is no statistical evidence to affirm that the size of the municipalities and the geographic location are not representative of the population, since there are no significant differences between what was observed and what is known about the population (size according to the number of inhabitants: $\chi_{(2)}^{2}=120.123 ; p=0.475$; and geographic location by region: $\chi_{(6)}^{2}=191.727$; $p=0.642$ ). In this manner, the representativeness of the sample in regard to the size and geographic location of the municipalities is guaranteed; therefore, the non-responses do not create a threat to the final conclusions based on the received responses.

In relation to the profile of the respondents by decision-maker group, the results obtained can be synthesized as follows:

- The majority of respondents (56.96 percent) had, at the time the questionnaire was applied, been at their positions/functions from one to nine years (Mean $=3.23$; $\mathrm{SD}=1.189$ ). A total of 30.77 percent of the decision makers had been at their current position from five to nine years, being that 22.6 percent had been at their positions for more than 15 years. A total of 44.68 percent of the political decision makers had worked from one to four years and 25.53 percent from five to nine years. The differences between the percentages, in relation to the groups of decision makers, appear to be justifiable by the number of years corresponding to the electoral period (four years). These facts allow for the consideration that it is the technical decision makers who seem to have sufficiently satisfactory experience in the position or function they perform, which is extremely important for this study, given their familiarity with the topic being studied, suggesting therefore a good quality of the source of data.

- Of the surveyed decision makers, 90.6 percent have a level of higher education. Two respondents hold doctorate degrees (within the group of political decision makers). It should be pointed out that the number of respondents with a high school diploma is reduced, reaching 9.94 percent. Keeping in mind that the questionnaire was directed at political and technical decision makers could, in some ways, justify these results. An analysis of the training areas of the respondents was also done, with economics/management as the prevailing answer (51.06 percent of the political decision makers and 69 percent of the technical decision makers), followed by "Other" in the majority of cases, in the area of law, specifically the political decision makers (22.34 percent). 
- In regard to age groups, an indicator of maturity, the majority of respondents were between 36 and 55 years old (Mean $=3.2 ; \mathrm{SD}=0.898$ ), being that 46.15 percent of the technical decision makers were between 36 and 45 years old and 41.89 percent of the political decision makers were between 46 and 55 years of age.
The usefulness of financial reporting

\subsection{Descriptive analysis of the results}

The univariate and bivariate techniques of statistics were used in order to analyse the results obtained. The univariate analysis consisted in carrying out, for each variable of the distribution of frequencies and in the determination of measures of central tendencies (mean and median), measures of dispersion (std deviation, minimum and maximum). The biavariate analysis consisted in the application of the independent-samples $t$ test and had as an objective, to verify if there were differences between the two groups of decision makers (political and technical) for each item of the different questions in the questionnaire.

For the validation and reliability of the set of measures, Cronbach's $\alpha(\alpha=0.985)$ was used, which led to the conclusion that the data of the different items of the questionnaire can be considered as unidimensional, since the values of the coefficient are above 0.800 , which allows for the effective validation of the dimensions. In other words, it can be affirmed that reliability of the questionnaire is quite acceptable and that its content is very good for the evaluation of the quality of the latent variable (Bryman and Cramer, 2011).

4.6.1 Usefulness of accounting statements - Official Local Government Accounting Plan. In regard to the usefulness of accounting statements prepared by POCAL for decision making, the results synthesized in Table II indicate that, in general, the majority of accounting statements were useful for decision making of the respondents (with a usefulness higher than the intermediate value of the scale). The Management Report and the Indebtedness Statement - Borrowings and Accounts Payable to Others are the most useful documents for the decision making of the respondents (with a mean level of usefulness of 4.53 and 4.52, respectively). These are in line with the results of Brusca (1997), in which the respondents also consider the Indebtedness Statement as very useful. The Budgetary Modifications Statement - Expenditure and Revenues, the Investments Multi-annual Plan Modification Statement, the Fixed and Variable Income Assets Statement and the Production Variation Statement are the documents which are indicated as the least useful, but even so, are superior to the intermediate value of the scale. The results obtained from the application of the $t$-student test (Table II, last column) indicate that the two groups of decision makers attribute, in general, a similar usefulness to the accounting statements (mandatory) for decision making, although statistically significant exceptions are registered in relation to seven items. For the majority of the documents, the group of technical decision makers attribute, on average, a greater usefulness to the accounting statements (mandatory), in comparison to the group of political decision makers. Nevertheless, the differences are statistically significant, for a $p$-value $<0.05$ in the Annual Execution Statement of Investment Multi-annual Plan, Current and Capital Transfers Statements - Revenue, the Obtained Grants Statements, the Statements of Gross Fixed Assets and Accumulated Depreciations and Adjustments and Fixed and Variable Income Assets Statement; for a $p$-value $<0.1$, the differences are significant in the Balance Sheet and Cash Flow Statement. 


\section{MRJIAM 11,2}

192

Table II.

Usefulness of accounting statements

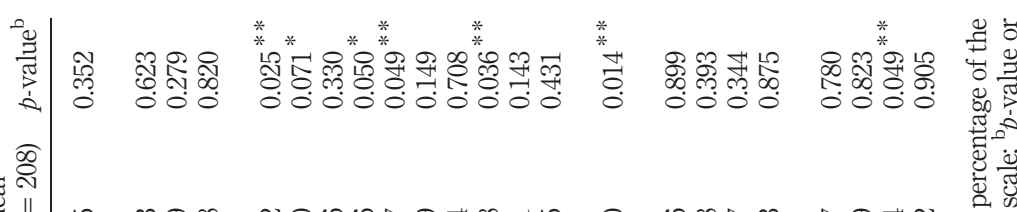

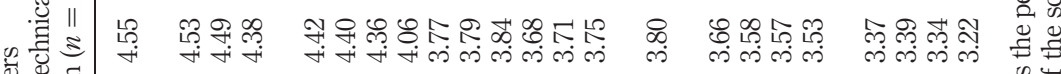

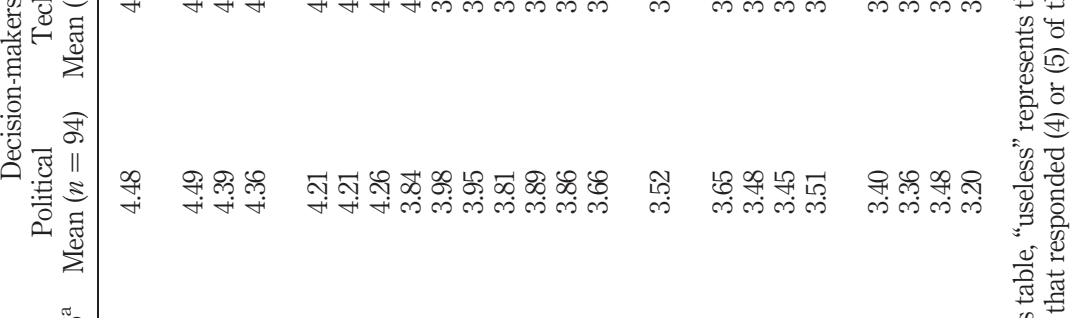

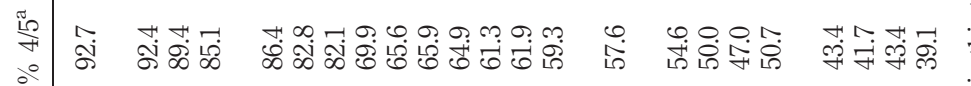

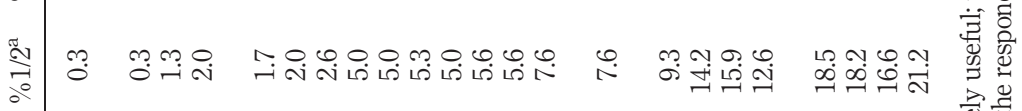

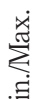

而

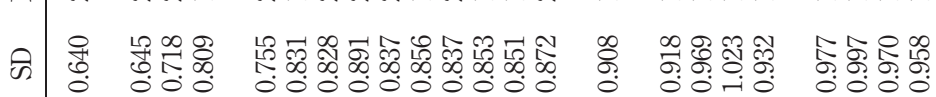

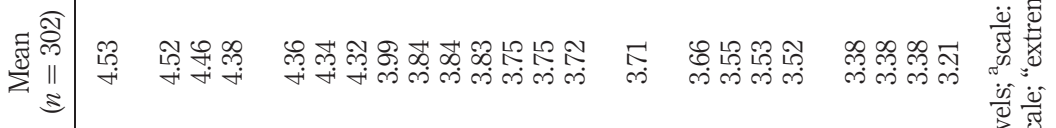

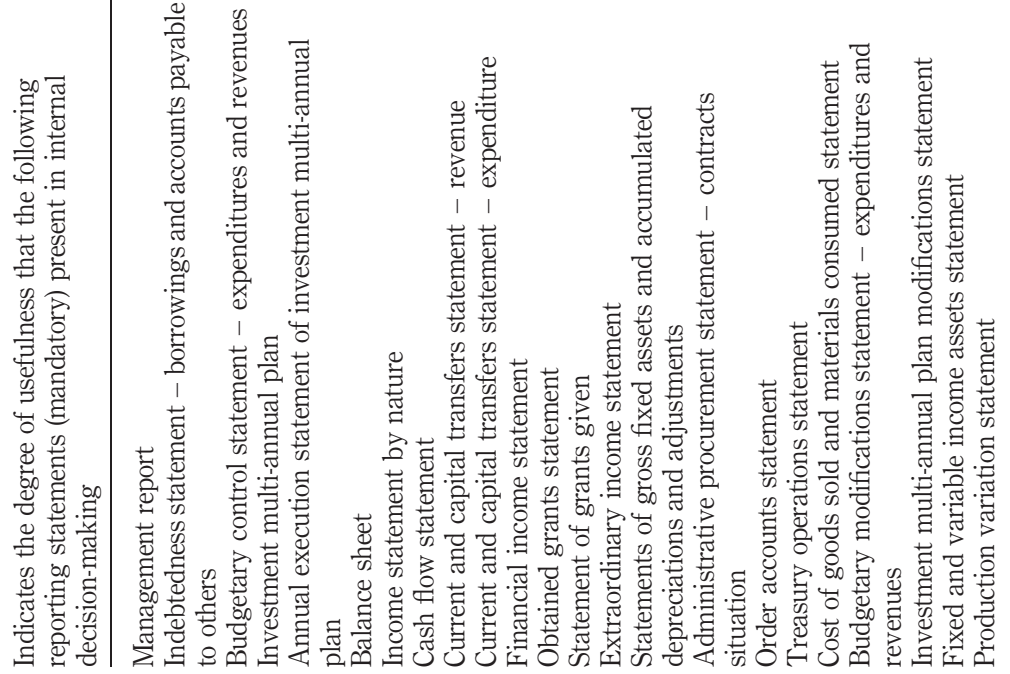

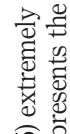


The results show that the information on the accounting statements are, in general, very useful either for the political decision makers or for the technical decision makers, being evident that the accrual-based information already presents a high usefulness for both of the internal decision makers. These results corroborate the studies of Andriani et al. (2010) and Kobert et al. (2010).

However, it is also verified that the Budgetary Statements continue to be the preferred ones for decision making, with average values of usefulness above those of the documents prepared on the accrual basis. Such conclusions tend to contradict the results of Robbins (1984), Jones et al. (1985), Hay and Antonio (1990), Daniels and Daniels (1991), Collins et al. (1991), Brusca (1997), Crain and Bean (1998), Priest et al. (1999) and Mack and Ryan (2006).

4.6.2 Usefulness of accrual-based information. For the purpose of knowing, in greater detail, the degree of usefulness of the patrimonial and financial information introduced in the current system of local government accounting information including the patrimonial accounting, the respondents were questioned about the usefulness of the different items of the Balance Sheet for internal decision making. The information regarding accounts payable - short- and medium-long term is the one that was shown to have the greatest usefulness for the decision making of the respondents (4.34). On average, it is verified that information concerning accounts receivable - short- and medium-long term (4.31) and regarding the Deposits in Financial Institutions and Cash (4.10) are also of great usefulness. With a lower average usefulness, but, even so, still above the intermediate level of the scale, is the information of the Revaluation Reserves (3.26) and of the Legal Statutory, Contractual, Free Reserves, Grants, Donations and Reserves resulting from Transfers of Assets (3.25), in other words, the information of the components of the Own Fund (Table III). In general, the technical decision makers attribute a greater usefulness to the patrimonial and financial information on the Balance Sheet, compared to the political decision makers, which confirms the results obtained in the previous analysis referring to the usefulness of the Balance Sheet (mandatory accounting statements) in providing assistance in the internal decision making of the respondents. The statistics reveal significant differences between political and technical decision makers only in regard to the fixed assets in Progress and tangible fixed assets $(p<0.05)$.

A similar analysis has tried to assess the usefulness of economic information (information disclosed in the income statement by nature, introduced in the local government accounting, the similarity of the information of the balance sheet with the inclusion of patrimonial accounting). The analysis in Table IV verifies that, on average, the respondents attribute a high usefulness to the information on staff costs (4.41), followed by the information items about taxes and fees and transfers and grants given (4.48). The elevated value of the staff costs seems to show the preoccupation on the part of the decision makers regarding what the weight of this component of the costs means for the municipalities. The significant usefulness attributed to Taxes and Fees appears to be normal, given the relevance that this source of incomes and revenues has for the municipalities. The information on the gross fixed assets and accumulated depreciation and adjustments is the item with the lowest usefulness (3.45), although higher than the intermediate value of the scale. The results obtained seem to confirm those from the analysis done to the usefulness of accounting statements (mandatory), specifically to the usefulness of the income statement by nature. On average, the group of technical

\section{The usefulness of financial reporting}

193 
MRJIAM

11,2

194

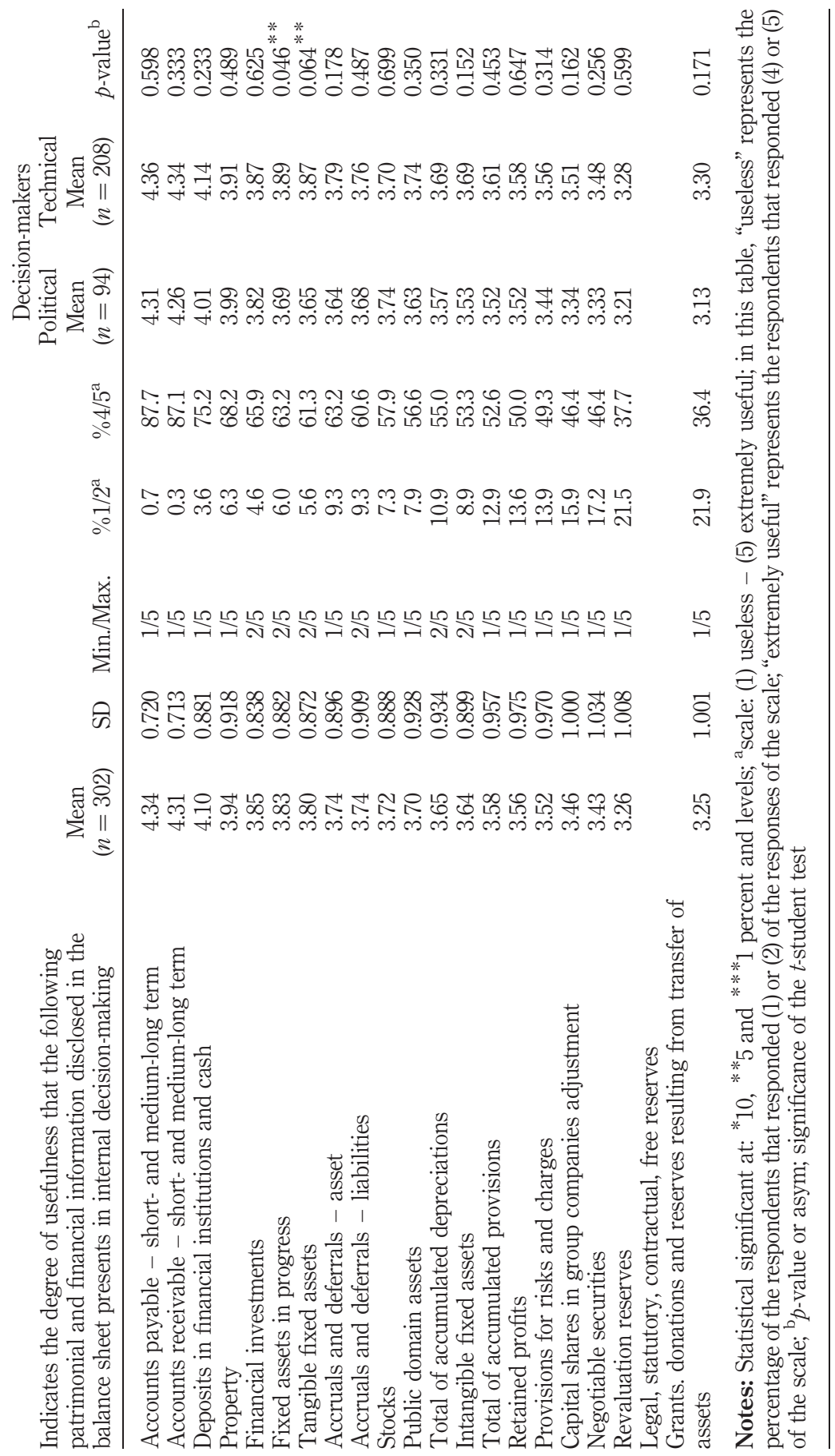

Table III.

Usefulness of patrimonial and financial information (balance sheet) 


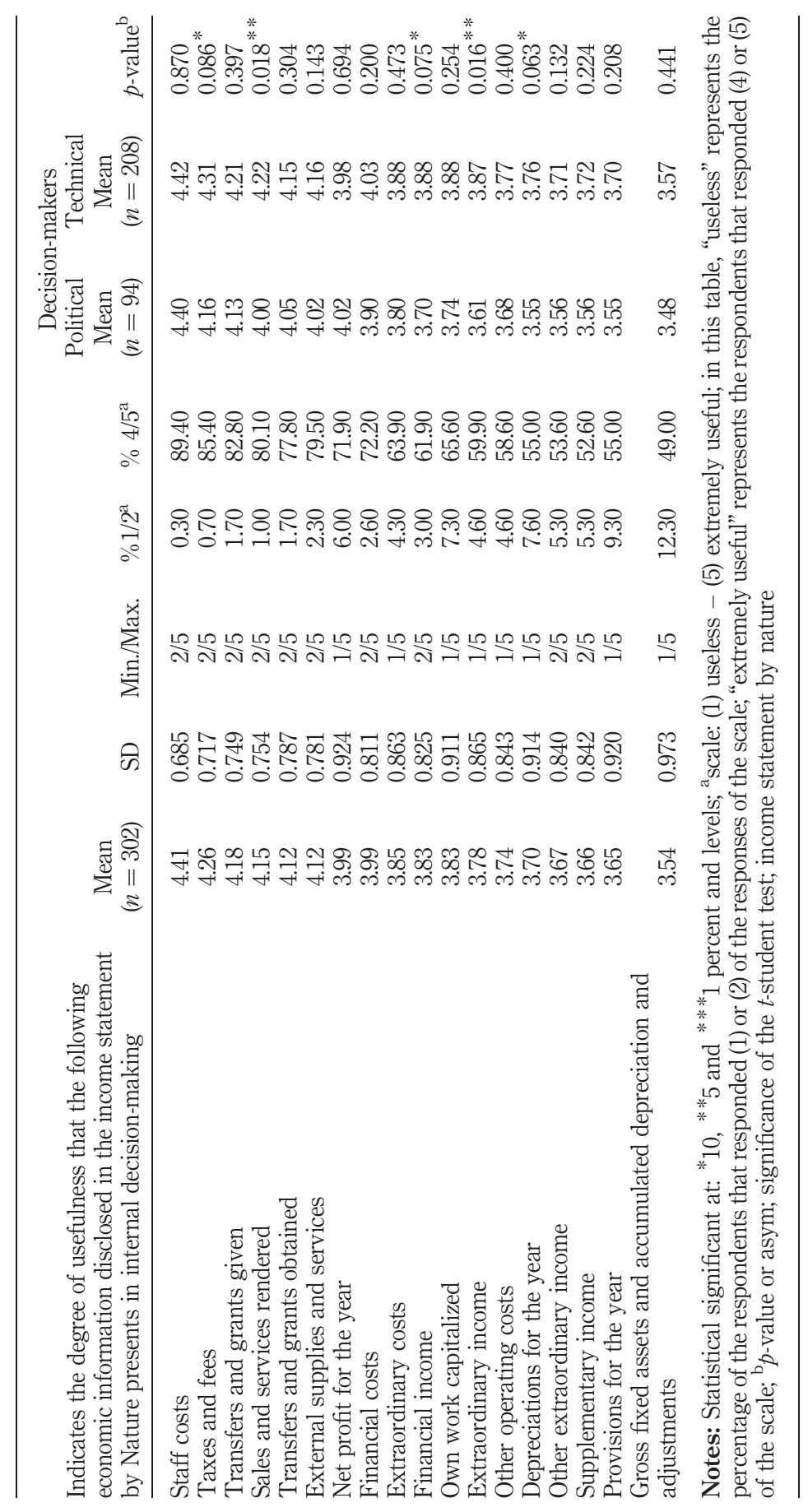

The usefulness of financial reporting

195

Table IV. Usefulness of economic information 
MRJIAM

11,2

196 decision makers attributed a greater usefulness to types of information about sales and services rendered, extraordinary income, taxes and depreciations for the year, when compared with the group of political decision makers. The differences are statistically significant for a $p<0.05$ in the first two situations and a $p<0.1$ in the remainders.

In a general way, in the cases in which the differences are statistically significant, the results obtained permit us to conclude, similarly to Paulsson (2006), that it is the technical decision makers who attribute a greater usefulness to the accrual-based information.

4.6.3 Usefulness of other financial information prepared and disclosed voluntarily. The decision makers were also surveyed in order to assess the usefulness, for internal decision making, of other documents or types of information, in addition to the ones that are mandatory to be disclosed in the annual accounts. The results in Table V show that the respondents consider the disclosure of other documents or types of information very useful. In the group of items referring to other documents, the Consolidated Management Report is the most useful document (with an average concordance of 3.63), being the Consolidated Income Statement by Functions the document with the lowest average. It is surprising to note that, similarly to the analysis of Table II, the Consolidated Management Report also appears here as being the most useful of the non-mandatory documents of the annual accounts. Relatively to the set of indicators presented[12], the respondents considered the information obtained through indicators developed based on the balance sheet as the most useful (3.96). From the set of indicators presented, developed based on the balance sheet, the calculation of the municipality Net Indebtedness is the most useful indicator for decision-making (4.33). This information corroborates the results of the previous analyses, namely regarding the need for financial information concerning the capacity for indebtedness and the usefulness attributed to accounts payable-short- and medium-long term. From the information obtained through the elaborated indicators based on the execution of the budget, the respondents attributed a greater usefulness to the information concerning staff expenditures vs total expenditures (4.19). The information obtained from the calculations of staff costs vs operational costs (4.07), elaborated based on the income statement by nature was the indicator with the highest usefulness. These results highlight, once again, the usefulness attributed to staff costs when surveyed on the usefulness of the economic information disclosed in the income statement by nature (Table IV). The differences regarding the usefulness of other documents or types of information for internal decision making do not appear to be statistically significant between the groups of decision makers.

The results obtained in the descriptive statistics are consistent with those of Jones et al. (1985) and Hay and Antonio (1990), whose studies show the usefulness of information on budget results and indicators of efficiency and efficacy. They are also in accordance with the results of Ter Bogt (2004) and Lee (2008), which show that users of financial information attribute usefulness to other types of information, in particular, on the performance in providing services and of a non-financial character, in addition to the information disclosed in the financial reporting.

\subsection{Tests of hypotheses}

To test the hypotheses, the bivariate analysis was also done with the application of Kruskal-Wallis, $\chi^{2}$ and one-sample $t$ tests. 


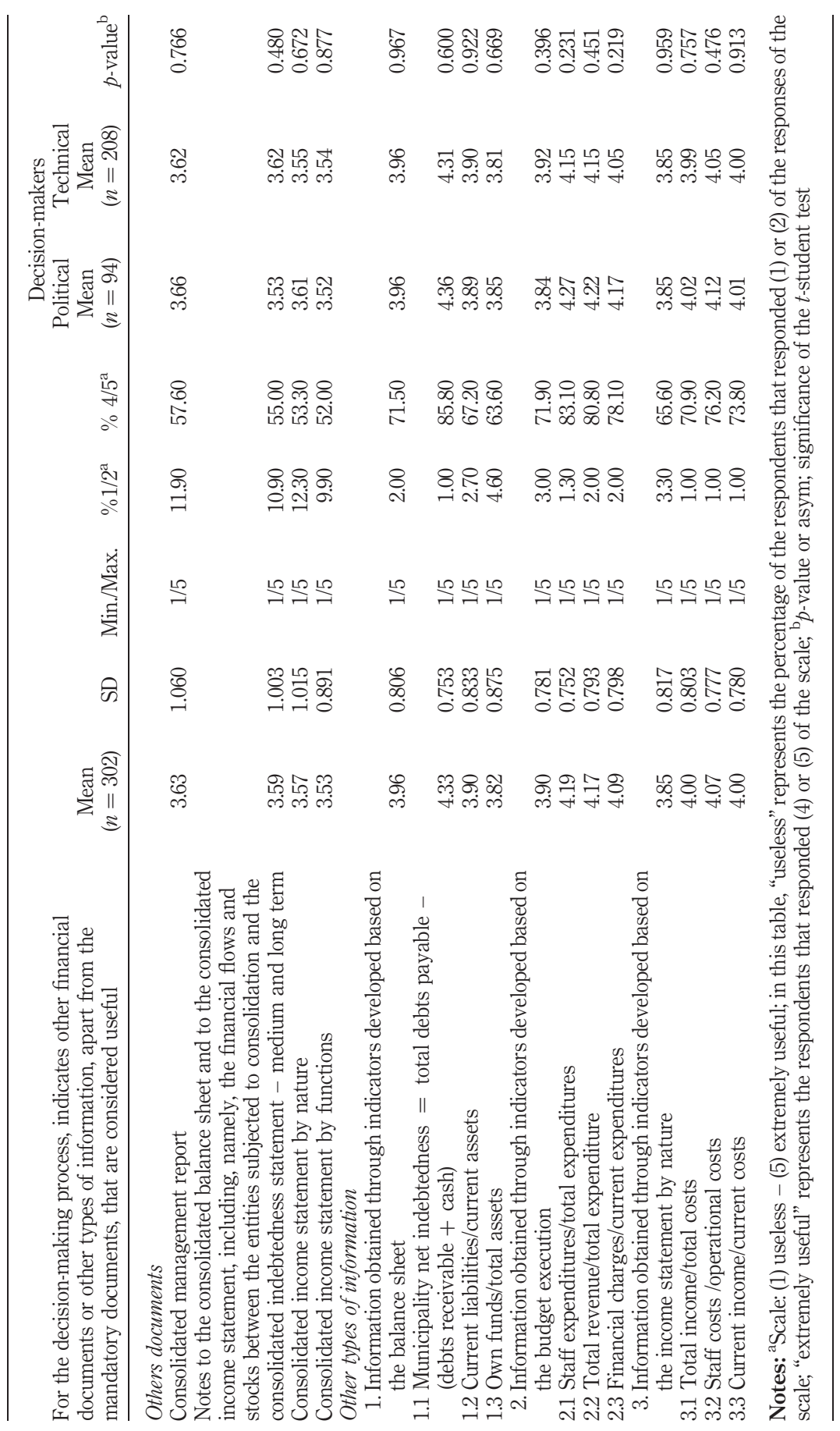

The usefulness of financial reporting

197

Table V. Usefulness of other documents and other financial information 
MRJIAM

11,2

198

The variables for the tests of hypotheses were constituted based on the simple average of items as part of each factor extracted from the factorial analysis in principal components of the scale, as suggested by Pestana and Gageiro (2008). The results of the factorial analysis of the dependent variables for the tests of the hypotheses are indicated in Table AI of the Appendix.

Thus, for the variable "usefulness of municipal financial reporting", the results of the KMO test (equal to 0.911) indicated that the quality of the correlations between the variables is very good (Pestana and Gageiro, 2008; Marôco, 2010). On the other hand, the results of Bartlett's test $(p<0.05, \alpha=0.000)$ demonstrated that there is a positive correlation between the variables $\left(\chi_{(351)}^{2}=8.077 .504\right)$.

Before performing the tests of hypotheses, and similarly to what was previously done, a descriptive analysis of the constituted variables was done, with the objective of knowing the general behavior adopted by the sample before the measured concepts. Five factors were extracted from the factorial analysis from which the global variable referred to was constituted. The results of the Cronbach's $\alpha$ showed a reasonable internal consistency - Cronbach's $\alpha$ equal to 0.755 (Pestana and Gageiro, 2008). The perception of the respondents on the usefulness of municipal financial reporting for internal decision making indicates that it is quite useful, with an average of 4.12.

In order to evaluate the first two hypotheses, statistical testing was performed to find out whether there is an association between the training area by group of decision makers and the usefulness of the municipal financial reporting. The results of the tests of Kruskal-Wallis $(p>0.05)$ revealed that, for a level of significance of 0.05 , there is no statistically significant association between the training area of the internal decision makers and the usefulness of the municipal financial reporting.

Taking into account the dispersion of the data on the training area when the crossing of the variables was realized, as they were initially defined, in a second analysis, the option was taken to group them into two categories following the methodology also adopted by Brusca (1997): one which includes the individuals (political decision makers, $n=61$ and technical decision makers, $n=175$ ) with training in management (economics/management, accounting and auditing), and the other which aggregates (political decision makers, $n=33$ and technical decision makers $=33$ ) those who have other types of training (engineering, law,....). For this analysis, the $\chi^{2}$ test was performed, which makes it possible to analyse the independence between two variables, rejecting the null hypothesis for any $p$-value less or equal to the determined probability of error of type I. The results obtained from the application of the test (political decision makers, $\chi_{(1)}^{2}=1.338 ; p=0.247$; technical decision makers, $\left.\chi_{(1)}^{2}=0.328 ; p=0.567\right)$ show that there is no statistically significant association between the variables. In these terms, the hypotheses ( $H 1$ and $H 2$ ) are refuted, in other words, there is no statistical evidence of an association between the training area of the respondents and the usefulness attributed to municipal financial reporting. The results obtained contradict the conclusion of Brusca (1997) and Yamamoto (2008). The fact that the studies of these authors are not focused on decision making and focus interchangeably on external and internal users could justify the difference of this empirical evidence.

In the third and fourth hypotheses, the association between the professional experience of the internal decision makers and the usefulness attributed to the municipal financial reporting was analysed. In order to do so, two groups of internal decision 
makers were created, taking into consideration the number of years they had been at their positions/functions. Thus:

(1) Group I - considerable professional experience: internal decision makers who have been at their positions/functions for five years or more.

(2) Group II - reduced professional experience: decision makers who have been at their positions/functions for less than five years.

In the case of the political decision makers, the frequencies revealed that 51 respondents (54.26 percent) pertain to group I and 43 respondents (45.74 percent) to group II. In the case of the technical decision makers, 154 respondents (74.04 percent) pertain to group I and 54 respondents (25.96 percent) to group II.

The results obtained from the $\chi^{2}$ test lead to the conclusion that there is no statistically significant association between the variables $(p=0.501$, political decision makers; $p=0.472$, technical decision makers), in other words, the null hypothesis which stipulates that the variables be independent is not rejected. Thus, it can be affirmed that there is no statistical evidence that confirm the association between professional experience and the usefulness of the municipal financial reporting of the internal municipal decision makers, thus refuting $H 3$ and $H 4$. This result is also contrary to the conclusions obtained by Yamamoto (2008) that show evidence that professional experience is positively associated with the usefulness attributed to the municipal financial reporting.

Also for the variable "usefulness of the accrual-based financial information", a factorial analysis was used. The results of the factorial analysis (Appendix) reveal the constitution of only one factor, that of the usefulness of information on the balance sheet. The results of the KMO test $(0.947)$ and the Bartlett's test $(p<0.001)$ indicate that the factorial analysis is very good and that it can provide satisfactory conclusions (Pestana and Gageiro, 2008; Marôco, 2010). In the same manner, the results of the factorial analysis of the variables affect the usefulness of the information disclosed in the income statement by nature leading to the constitution of only one factor that explains 74.34 percent of the total variance of the responses. The results of the KMO test (0.944) indicate that the quality of the correlations between the variables is very good (Pestana and Gageiro, 2008; Marôco, 2010). On the other hand, the results of Bartlett's test revealed that there is a positive correlation between the variables $(p<0.001)$. According to the referred methodology, based on the average of the factors extracted, the variable "usefulness of the accrual-based financial information" was constituted, whose results of the coefficient of Cronbach's $\alpha$ (equals to 0.975 ) indicate a very good internal consistency (Pestana and Gageiro, 2008; Marôco, 2010).

In order to verify the usefulness of patrimonial, financial and economic information (elaborated on the accrual basis) for internal decision makers in assisting them in making decisions (H5), the parametric $t$-student test was performed to obtain a sample. Taking into consideration the defined scales (1-“Useless" to 5-"Very useful") to assess the usefulness of the accrual-based information, for the internal decision-making process of the municipal users, the scale 3 (useful) was taken as a reference value for the execution of the test. Thus, the intention was to test:

$H_{O}$. The average of the usefulness of the accrual-based information for internal decision makers is equal or inferior to 3 .
The usefulness of financial reporting

199 
MRJIAM

11,2

200
$H_{a}$. The average of the usefulness of the accrual-based information for internal decision makers is greater than 3 .

The results obtained show that for a level of significance of 0.05 , there is statistical evidence to affirm that the average of the usefulness of accrual-based information for internal decision making is superior to $3(p<0.001)$, measured on a scale of 1 (useless) to 5 (very useful). It is estimated that, with a 95 percent confidence interval, the average of the usefulness of the accrual-based information for decision-making is between 3.6 and 4.9, being that the interval of the difference between the higher average of the political decision makers and the lower average attributed by the technical decision makers is 0.114, which means that it is the technical decision makers who, in comparison with the political decision makers, attribute a greater usefulness to the accrual-based information. These results are not surprising given the accounting knowledge of the technicians of the financial area, and corroborate Paulsson's (2006) conclusions, when he suggests that the accrual-based information is more useful for the technicians than for the politicians. Thus, H5 is rejected, which leads to the conclusion that accrual-based information is attributed usefulness as high as is attributed to budgetary cash-based information. This empirical evidence confirms the conclusions of Guthrie (1998), Chan (2003), Van der Hoek (2005), Kober et al. (2010) and Andriani et al. (2010), and could also be justified by considering the familiarity of the users with the information prepared by accrual accounting.

\section{Conclusions}

Internationally, during recent decades, the actions of the leaders of local entities, namely in regard to the utilization and usefulness of public resources, have become a fundamental preoccupation in the context of the NPM. As a response to the new needs of information of local government's leaders, changes were introduced in the accounting information systems that, among others, altered the form and content of the financial and budgetary statements prepared and disclosed by the local entities.

In this context, this study centered itself on the analysis of financial information, that is expected to be prepared and disclosed by the municipalities in Portugal, as assistance in the internal decision-making process by the leaders of the local governments, contributing to the analysis of the usefulness of the current municipal financial reporting and indicating the mandatory accounting statements, but also other documents or types of information of greater or lesser usefulness for internal decision making. In addition, it tried to verify the usefulness of the accrual-based information, inasmuch as one of the principal recent changes in local government accounting was the adoption of the financial reporting model based on the model of financial reporting of the business sector, with the objective of disclosing useful financial information for decision making and internal control.

In regard to the first question of the study (documents of greatest usefulness), the empirical analysis shows that the Management Report and the Indebtedness Statement (Borrowings and Accounts Payable to Others) are the mandatory accounting statements with the highest usefulness for decision making by the respondents. The Budgetary Modifications Statement - Expenditures and Revenues, the Investment Multi-annual Plan Modifications Statement, the Fixed and Variable Income Assets Statements and the Production Variation Statement are the documents that indicate the most reduced usefulness but, even so, above the intermediate value of the scale. 
In regard to the second question (usefulness of accrual-based information), the results reveal that, in general, the budgetary cash-based statements are the most useful ones, still with a minor difference, for internal decision making when compared with the patrimonial, financial and economic information statements, elaborated on the accrual-basis. Nevertheless, it is verified that the usefulness attributed by the respondents to the accrual-based statements is, therefore still high, which means that the users are beginning to use the accrual-based information more for the process of internal decision making. Such evidence suggests that the usefulness of accrual-based information, understood by internal decision makers, is increasing with time. Such a fact could be justified by taking into account the familiarity of the respondents with this information and having more experience with the current system of local government accounting, inasmuch as it has been more than a decade after its introduction with the POCAL.

In regard to the third question (usefulness of non-mandatory documents and other types of information), it was verified that the usefulness attributed is also quite high, as assistance in the process of internal decision making to the disclosure of other types of information prepared voluntarily.

Differences were also found, though reduced, between the groups of decision makers - political and technical - regarding the usefulness attributed to the financial reporting elaborated and divulged in the Portuguese municipalities, in the context of internal decision making. However, the differences were not sufficiently significant. In addition, and in answer to the fourth question of the study (the association between the profile of the respondents and the usefulness attributed to the municipal financial reporting), there is no statistical evidence that relates the area of training and professional experience of the internal decision makers with the usefulness attributed to the municipal financial reporting.

In summary, the results of the empirical study show a high usefulness of the municipal financial reporting for the internal decision makers (political and technical), although such usefulness could be increased with the introduction of voluntary information and some adjustments to the contents of the mandatory budgetary and financial statements, that indicate considerable usefulness. These results are consistent with other studies that show that although the financial reporting statement is useful (Brusca, 1997; Mack and Ryan, 2006), considerable usefulness is also attributed to other types of non-mandatory information for preparation and disclosure (Lee, 2008), that assist in taking decisions in a more rational and logical manner. In addition, in the cases where the differences are statistically significant, the decision makers are the ones who attribute greater usefulness to the accrual-based information, which has also found support in some analysed literature (Paulsson, 2006).

Although this study presents some interesting conclusions, it also has some limitations. Considering that the basic approach that was chosen was a cross-section study and methods of quantitative analysis, the first limitation is the fact that this type of analysis allows for associations to be established, but not causality. The use of only one instrument (a questionnaire) to measure all the variables of the study could also have skewed the answers of the respondents and caused the variance of the common method. Another aspect which could have affected the results is the "noisiness of the measures". The application of the questionnaire by email does not allow for the evaluation of the truthfulness and integrity of the responses, in addition to not allowing for an evaluation of the real knowledge of the municipal financial reporting to be

\section{The usefulness of financial reporting}

201 
MRJIAM 11,2

202 possible, even though the questionnaires were sent directly to the top person responsible for the finance area. Indeed, the measurement of the usefulness of the municipal financial reporting is based on the opinions of the respondents (perceptive measures) and not on objective measures which, on the one hand, does not allow for a rigorous and clear interpretation of the results and, on the other hand, could have threatened the internal validity of the study.

In spite of these limitations, this study contributed to the scientific literature regarding the reform of accounting systems and of financial reporting of the local administration, providing as much of our knowledge as possible, on the first cross-section evaluation of the usefulness of the financial reporting of the Portuguese municipalities for the decision makers. From a more practical perspective, knowledge concerning the usefulness of financial reporting can help the regulatory bodies to improve the current model of municipal financial reporting in future reforms of local government accounting, bearing in mind the experience of the internal decision makers of the Portuguese municipalities.

\section{Notes}

1. Law 8/90, February 20.

2. Decree-Law 155/92, July 28.

3. Law-decree 232/97, September 3.

4. Law-decree n. ${ }^{\circ}$ 54-A/99, February 22.

5. The issues dealt in this paper derive from applying a more extensive questionnaire. However, taking into account the purposes of this study, we chose to only present in Appendix the questions that allow the measurement of the necessary variables.

6. Financial Department or Financial Division or Accounting Section, according to the organizational structure of the municipality.

7. The senior financial officials of municipalities were considered as stakeholders in the decision-making process since they provide technical opinions to the decision-making of top managers.

8. By asking heads of financial departments and auditors, Brusca (1997) found that the legislative bodies and the heads of financial-economic management were considered the most important internal users of financial information of Spanish municipalities.

9. See, for example, Jones et al., 1985 - 10 percent; Priest et al., 1999 - 19 percent; Brusca, 1997 - 38.5 percent; Andriani et al., 2010 - 23 percent; and Kober et al., 2010 - 21 percent. Additionally, in accounting research responders rates below 25 percent are frequent (Smith, 2003).

10. The number of inhabitants was obtained from the statistics published by the National Institute of Statistics (www.ine.pt) concerning the 2011 Census.

11. Small-sized municipalities: population less than or equal to 20000 inhabitants; medium-sized municipalities: population greater than 20000 inhabitants and less than or equal to 100000 inhabitants; and large-sized municipalities: population over 100000 inhabitants.

12. The set of indicators presented in this investigation resulted, on the one hand, from the Carvalho et al. (2008) indicators and, on the other hand, from a search made to Management Reports of 2010 (mandatory document of accounting statements) of some municipalities, choosing the most frequent indicators. 


\section{References}

Andriani, Y., Kober, R. and Ng, J. (2010), "Decision usefulness of cash and accrual information: public sector managers' perceptions”, Australian Accounting Review, Vol. 20 No. 53, pp. 144-153.

Anessi-Pessina, E. and Steccolini, I. (2007), "Effects of budgetary and accruals accounting coexistence: evidence from Italian local governments", Financial Accountability \& Management, Vol. 23 No. 2, pp. 113-131.

Barbosa, C. (2006), "Public accounting: its users and its information needs - a study on the health sector - the Hospital Centre of Vila Nova de Gaia”, Master Dissertation - Administration and Accounting, University of Minho, Braga.

Brorström, B. (1998), “Accrual accounting, politics and politicians”, Financial Accountability \& Management, Vol. 14 No. 4, pp. 319-333.

Brusca, I. (1997), "The usefulness of financial reporting in Spanish local governments”, Financial Accountability \& Management, Vol. 13 No. 1, pp. 17-34.

Brusca, I. and Condor, V. (2002), "Towards the harmonization of local accounting systems in the international context", Financial Accountability \& Management, Vol. 18 No. 2, pp. 129-162.

Bryman, A. and Cramer, D. (2011), Quantitative Data Analysis with IBM SPSS Statistics 17, 18 and 19: A Guide for Social Scientists, Psychology Press, Hove.

Budding, G. (2004), “Accountability, environmental uncertainty and government performance: evidence from Dutch municipalities”, Management Accounting Research, No. 15, pp. 285-304.

Caba, C., López, A. and Ortiz, D. (2009), "Governmental financial information reforms and changes in the political system: the Argentina, Chile and Paraguay experience", Public Administration and Development, No. 29, pp. 429-440.

Carvalho, J., Fernandes, M., Camões, P. and Jorge, S. (2008), Annual Financial Report of Portuguese Local Government - 2006, Order of Chartered Accountants, Lisbon.

Carvalho, J., Fernandes, M., Camões, P. and Jorge, S. (2010), Annual Financial Report of Portuguese Local Government - 2008, Order of Chartered Accountants, Lisbon.

Chan, J. (2003), "Government accounting: an assessment of theory, purposes and standards", Public Money and Management, No. 23, pp. 13-20.

Christiaens, J. (1999), "Financial accounting reform in Flemish municipalities: an empirical investigation”, Financial Accountability \& Management, Vol. 15 No. 1, pp. 21-40.

Christiaens, J. and Rommel, J. (2008), “Accrual accounting reforms: only in businesslike (parts of) governments”, Financial Accountability \& Management, Vol. 24 No. 1, pp. 59-75.

Cohen, S. (2007), "How different are accrual accounting financial measures compared to cash accounting ones? Evidence from Greek municipalities", paper presented at 6th Annual Conference of the Hellenic Accounting and Finance Association, Patra, December 14-15.

Cohen, S. (2009), "Cash versus accrual accounting measures in Greek municipalities: proxies or not for decision-making?", available at: http://ssrn.com/abstract=1031089 (accessed October 18 2009).

Cohen, S., Kaimenakis, N. and Zorgios, Y. (2007), "Assessing IT as a key success factor for accrual accounting implementation in Greek municipalities", Financial Accountability \& Management, Vol. 23 No. 1, pp. 91-111.

\section{The usefulness of financial reporting}

203 
MRJIAM 11,2

204
Collins, W., Keenan, D. and Lapsley, I. (1991), Local Authority Financial Accounting Communication Sophistry or Obfuscation, The Chartered Institute of Public Finance and Accountancy, Edinburgh.

Crain, G. and Bean, D. (1998), "What users think of the new reporting model for government: the results of the GASB's focus group sessions", Government Finance Review, Vol. 14 No. 1, pp. 9-13.

Daniels, J. and Daniels, C. (1991), "Municipal financial reports: what users want", Journal of Accounting and Public Policy, Vol. 10 No. 1, pp. 15-38.

Davila, T. and Oyon, D. (2008), "Cross-paradigm collaboration and the advancement of management accounting knowledge", Critical Perspectives on Accounting, Vol. 19 No. 6, pp. 887-893.

Ferreira, L. and Sarmento, M. (2009), "Qualitative research in accounting: a research survey", in Major, M. and Vieira, R. (Eds), Accounting and Management Control - Theory, Methodology and Practical, School Publishing, Lisbon.

Gillham, B. (2008), Developing a Questionnaire (Real World Research), 2nd ed., Continuum International Publishing Group Ltd, London.

Grossi, G. and Reichard, C. (2009), "The limited use of financial data for governmental decision-making - an exploratory study with reference to Germany and Italy", paper presented at 12th Biennial Comparative International Governmental Accounting Research (CIGAR) Conference - New Challenges for Public Sector Accounting, May, Modena.

Guthrie, J. (1998), "Application of accrual accounting in the Australian public sector - Rhetoric or reality?", Financial Accountability \& Management, Vol. 14 No. 1, pp. 1-19.

Guthrie, J., Olson, S. and Humphrey, C. (1999), "Debating developments in new public financial management: the limits of global theorizing and some new ways forward", Financial Accountability \& Management, Vol. 15 Nos 3/4, pp. 209-228.

Hay, L. and Antonio, J. (1990), "What users want in government financial reports", Journal of Accountancy, pp. 91-98.

Hodges, R. and Mellett, H. (2003), "Reporting public sector financial results”, Public Management Review, Vol. 5 No. 1, pp. 99-113.

Hood, C. (1991), “A public management for all seasons?”, Public Administration, Vol. 69 No. 1, pp. 3-19.

Hood, C. (1995), "The new public management in the 1980s: variations on a theme", Accounting, Organizations and Society, Vol. 20 No. 2, pp. 93-109.

Hookana, H. (2008), "Organizational culture and the adoption of new public management practices", Management Journal, Vol. 3 No. 4, pp. 309-327.

Hopper, T. and Powell, A. (1985), "Making sense of research into organizational and social aspects of management accounting: a review of its underlying assumptions", Journal of Management Studies, Vol. 22 No. 5, pp. 429-465.

Hyndman, N. and Connolly, C. (2011), "Accruals accounting in the public sector: a road not always taken”, Management Accounting Research, No. 22, pp. 36-45.

International Federation of Accountants (IFAC) (2002), Financial Reporting by National Governments, Public Sector Committee, New York, NY, Study 1, March.

International Public Sector Accounting Standards Board (IPSASB) (2010), Conceptual Framework for General Purpose Financial Reporting by Public Sector Entities, Conceptual Framework Exposure Draft 1, IFAC, New York, NY.

Jones, R., Scott, R., Kimbro, L. and Ingram, R. (1985), The Needs of Users of Governmental Financial Reports, Government Accounting Standards Board, Stamford, CT. 
Kober, R., Lee, J. and Ng, J. (2010), "Mind your accruals: perceived usefulness of financial information in the Australian public sector under different accounting systems", Financial Accountability \& Management, Vol. 26 No. 3, pp. 267-298.

Lapsley, I. (1999), "Accounting and the new public management: instruments of substantive efficiency or a rationalizing modernity?”, Financial Accountability \& Management, Vol. 15 Nos 3/4, pp. 201-207.

Lapsley, I. (2009), "New public management: the cruelest invention of the human spirit?", Abacus, Vol. 45 No. 1, pp. 1-21.

Lee, J. (2008), "Preparing performance information in the public sector: an Australian perspective", Financial Accountability \& Management, Vol. 24 No. 2, pp. 117-149.

López, A. and Caba, C. (2004), "The relevance of Spanish local financial reporting to credit institution decisions: an empirical study", The International Journal of Public Sector Management, Vol. 17 No. 2, pp. 118-135.

Lüder, K. (1992), “A contingency model of government accounting innovations in the political administrative environment", Research in Governmental and Nonprofit Accounting, No. 7, pp. 99-127.

Lukka, K. (2010), "The roles an effects of paradigms in accounting research", Management Accounting Research, Vol. 21 No. 2, pp. 110-115.

Mack, J. (2004), "An investigation of the information requirements of users of Australian public sector financial report", unpublished $\mathrm{PhD}$ thesis, Queensland University of Technology, Brisbane.

Mack, J. and Ryan, C. (2006), "Reflections on the theoretical underpinnings of the general-purpose financial reports of Australian government departments", Accounting, Auditing and Accountability Journal, Vol. 19 No. 4, pp. 592-612.

Mack, J. and Ryan, C. (2007), "Is there an audience for public sector annual reports: Australian evidence?", International Journal of Public Sector Management, Vol. 20 No. 2, pp. 134-146.

Marôco, J. (2010), Statistical Analysis with PASW Statistics, 5th ed., Pero Pinheiro, ReportNumber.

Montesinos, V. and Brusca, I. (2009), "Accrual versus cash basis in the public sector: where are the differences in practice?", paper presented at 12th Biennial Comparative International Governmental Accounting Research (CIGAR) Conference: New Challenges for Public Sector Accounting, Modena.

Montesinos, V., Pina, V., Torres, L. and Vela, J. (1995), “Comparative analysis of governmental accounting systems in OECD countries: an empirical approach", in Montesinos, V. and Vela, J. (Eds), International Research in Public Sector Accounting, Reporting and Auditing, Institute of Economics Research, Valencia.

Olson, J., Guthrie, J. and Humphrey, C. (1998), "Global warning: debating international developments", in Olson, J. (Ed.), New Public Financial Management (NPFM) Reforms: New World? Small World? Better World?, Cappelen Akademisk, Oslo.

Olson, O. and Shalin-Andersson, K. (1998), "Accounting transformation in an advanced welfare state: the case of Sweden", in Olson, O., Guthrie, J. and Humphrey, C. (Eds), Global Warning, Akademisk Forlag, Copenhagen.

Ouda, H. (2007), "Accrual accounting in the government sector, background, concepts, benefits and costs", The International Consortium on Governmental Financial Management, Vol. 6 No. 1, pp. 39-52.

\section{The usefulness of financial reporting}

205 
MRJIAM 11,2
Pallot, J. (1997), "Infrastructure accounting for local authorities: technical management and political context", Financial Accountability \& Management, Vol. 13 No. 3, pp. 225-242.

Paulsson, G. (2006), "Accrual accounting in the public sector: experiences from the central government in Sweden”, Financial Accountability \& Management, Vol. 22 No. 1, pp. 47-62.

Pestana, M. and Gageiro, J. (2008), Data Analysis for Social Sciences: The Complementarily of SPSS, 5th ed., Sílabo, Lisbon.

Pina, V. and Torres, L. (2003), "Reshaping public sector accounting: an international comparative view", Canadian Journal of Administrative Sciences, Vol. 20, pp. 334-350.

Pina, V., Torres, L. and Yetano, A. (2009), "Accrual accounting in EU local governments: one method, several approaches”, European Accounting Review, Vol. 18 No. 4, pp. 765-807.

Priest, A., Ng, J. and Dolley, C. (1999), "Users of local government annual reports: information preferences”, Accounting, Accountability and Performance, Vol. 5 No. 3, pp. 49-62.

Robbins, W. (1984), "Consensus between prepares and users of municipal annual reports: an empirical analysis", Accounting and Business Research, Spring, pp. 157-162.

Smith, M. (2003), Research Methods in Accounting, Sage, Thousand Oaks, CA.

Tayib, M., Commbs, H. and Ameen, J. (1999), "Financial reporting by Malaysian local authorities: a study of the needs and requirements of the users of local authority financial accounts", Financial Accountability \& Management, Vol. 12 No. 2, pp. 103-120.

Ter Bogt, H. (2004), "Politicians in search of performance information? Survey research on Dutch Aldermen's use of performance information", Financial Accountability \& Management, Vol. 20 No. 3, pp. 221-252.

Van der Hoek, M. (2005), "From cash to accrual budgeting and accounting in the public sector: the Dutch experience", Public Budgeting and Finance, Vol. 25 No. 1, pp. 32-45.

Van Helden, G. and Ter Bogt, H. (2001), "The application of businesslike planning and control in local government: a field study of eight Dutch municipalities", Local Government Studies, Vol. 27 No. 1, pp. 61-86.

Vieira, R. (2009), "Theoretical paradigms research in accounting", in Major, M. and Vieira, R. (Eds), Accounting and Management Control: Theory, Methodology and Practical, Scholar Editora, Lisbon.

Windels, P. and Christiaens, J. (2008), "The adoption of accrual accounting in Flemish public centers for social welfare: examining the importance of agents of change", in Jorge, S. (Ed.), Implementing Reforms in Public Sector Accounting, Coimbra University Press, Coimbra.

Wynne, A. (2008), "Accrual accounting for the public sector - a fad that has had its day?”, International Journal of Governmental Financial Management, Vol. 9 No. 2, pp. 117-132.

Yamamoto, K. (2008), "What Matters in Legislators' information use for financial reporting? - the case of Japan", in Jorge, S. (Ed.), Implementing Reforms in Public Sector Accounting, Coimbra University Press, Coimbra.

\section{Further reading}

Federation of European Accountants (2007), Accrual Accounting in the Public Sector, Federation of European Accountants, Brussels.

Jones, R. and Pendlebury, M. (2000), Public Sector Accounting, 5th ed., Pitman Publishing, London.

Jones, R. and Pendlebury, M. (2004), "A theory of the published accounts of local authorities", Financial Accountability \& Management, Vol. 20 No. 3, pp. 305-325. 
Appendix

1.1. Questionnaire for Political and Technical Responsible for the Financial Area of the Portuguese Municipalities

1. On a scale of 1 to 5, where 1 is Useless and 5 is Extremely useful, indicate the degree of usefulness that the following reporting statements (mandatory) present in internal decision-making: (mark your answer with a circle)

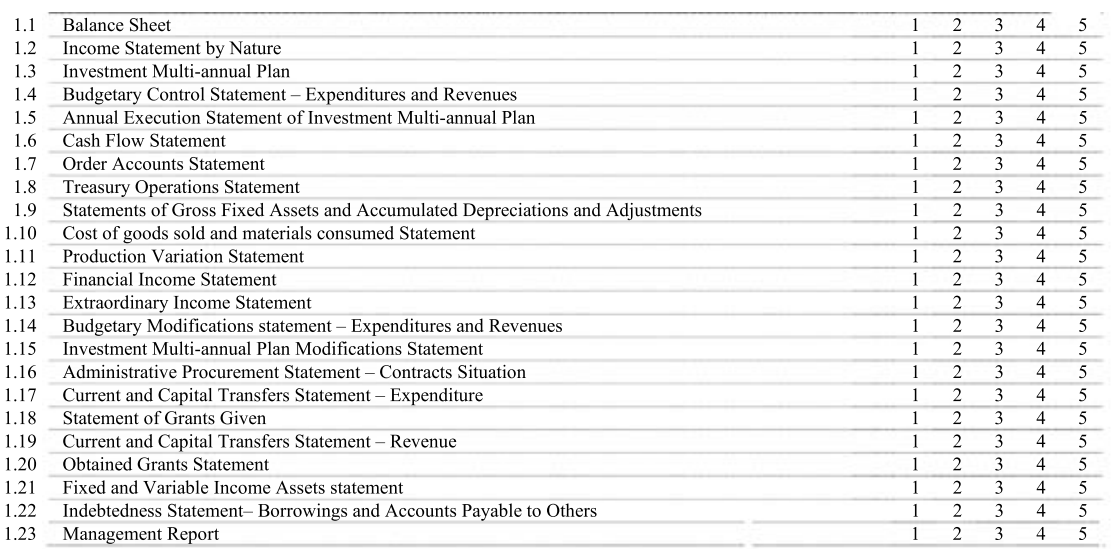

2. On a scale of 1 to 5, where 1 is Useless and 5 is Extremely useful, indicate the degree of usefulness that the following patrimonial and financial information disclosed in the Balance Sheet presents in internal decision-making: (mark your answer with a circle)

\begin{tabular}{|c|c|c|c|c|c|}
\hline Public Domain Assets & 1 & 2 & 3 & 4 & 5 \\
\hline Intangible Fixed Assets & 1 & 2 & 3 & 4 & 5 \\
\hline Tangible Fixed Assets & 1 & 2 & 3 & 4 & 5 \\
\hline Fixed Assets in Progress & 1 & 2 & 3 & 4 & 5 \\
\hline Financial Investments & 1 & 2 & 3 & 4 & 5 \\
\hline Stocks & 1 & 2 & 3 & 4 & 5 \\
\hline Accounts Receivable - Short and Medium-Long term & 1 & 2 & 3 & 4 & 5 \\
\hline Negotiable Securities & 1 & 2 & 3 & 4 & 5 \\
\hline Deposits in Financial Institutions and Cash & 1 & 2 & 3 & 4 & 5 \\
\hline Accruals and Deferrals - Asset & 1 & 2 & 3 & 4 & 5 \\
\hline Property & 1 & 2 & 3 & 4 & 5 \\
\hline Capital Shares in Group Companies Adjustment & 1 & 2 & 3 & 4 & 5 \\
\hline Revaluation Reserves & 1 & 2 & 3 & 4 & 5 \\
\hline $\begin{array}{l}\text { Legal. Statutory, Contractual, Free Reserves. Grants. Donations and Reserves resulting from } \\
\text { Transfer of Assets }\end{array}$ & 1 & 2 & 3 & 4 & 5 \\
\hline Retained Profits & 1 & 2 & 3 & 4 & 5 \\
\hline Provisions for Risks and Charges & 1 & 2 & 3 & 4 & 5 \\
\hline Accounts payable - Short and Medium-Long Term & 1 & 2 & 3 & 4 & 5 \\
\hline Accruals and Deferrals - Liabilities & 1 & 2 & 3 & 4 & 5 \\
\hline Total of Accumulated Depreciations & 1 & 2 & 3 & 4 & 5 \\
\hline Total of Accumulated Provisions & 1 & 2 & 3 & 4 & 5 \\
\hline
\end{tabular}

3. On a scale of 1 to 5, where is 1 Useless and 5 is Extremely useful, indicate the degree of usefulness that the following economic information disclosed in the Income Statement by Nature presents in internal decision-making: (mark your answer with a circle)

3.1 Gross Fixed Assets and Accumulated Depreciation and Adjustments

3.2 External Supplies and Services

3.3 Staff Costs

3.4 Transfers and Grants Given

3.5 Depreciations for the year

3.6 Provisions for the year

3.7 Other Operating Costs

3.8 Financial Costs

3.9 Extraordinary Costs

3.10 Sales and Services Rendere

3.11 Taxes and Fees

3.12 Transfers and Grants Obtained

3.13 Own Work Capitalized

\begin{tabular}{lllll}
1 & 2 & 3 & 4 & 5 \\
1 & 2 & 3 & 4 & 5 \\
1 & 2 & 3 & 4 & 5 \\
\hline 1 & 2 & 3 & 4 & 5 \\
1 & 2 & 3 & 4 & 5 \\
\hline 1 & 2 & 3 & 4 & 5 \\
1 & 2 & 3 & 4 & 5 \\
1 & 2 & 3 & 4 & 5 \\
1 & 2 & 3 & 4 & 5 \\
1 & 2 & 3 & 4 & 5 \\
\hline 1 & 2 & 3 & 4 & 5 \\
1 & 2 & 3 & 4 & 5 \\
\hline 1 & 2 & 3 & 4 & 5 \\
\hline & \multicolumn{4}{c}{ (continued) }
\end{tabular}




\section{MRJIAM 11,2}

\begin{tabular}{lllllll}
3.14 & Extraordinary Income & 1 & 2 & 3 & 4 & 5 \\
\hline 3.15 & Other Operating Income & 1 & 2 & 3 & 4 & 5 \\
3.16 & Financial Income & 1 & 2 & 3 & 4 & 5 \\
\hline 3.17 & Extraordinary Income & 1 & 2 & 3 & 4 & 5 \\
\hline 3.18 & Net Profit for the year & 1 & 2 & 3 & 4 & 5 \\
\hline
\end{tabular}

4. For the decision-making process, indicate other financial documents or other types of information, apart from the mandatory documents, that are considered useful: (for each item marks your answer with a circle considering the scale from 1 to 5, where is 1 Useless and 5 is Extremely useful)

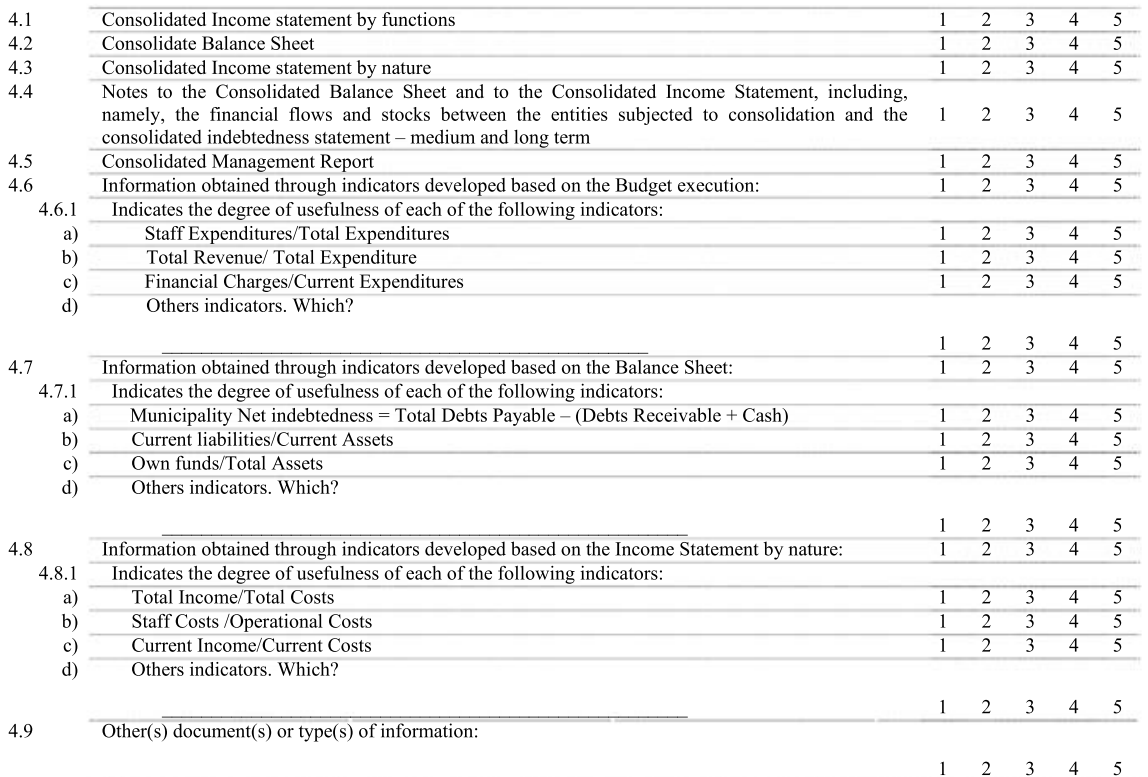

5. What is the position that occupies in the municipality?

$\square$ Political

Technical

6. How many years assume the current position? (please mark your response)
$\square<1$ year
$\square 1$ - 4 years
$5-9$ years
$\square 10-14$ years

7. What is your educational level? (please mark your response)

$\begin{array}{ll}\square \text { Doctorate } & \square \text { Bachelor } \\ \square \text { Master } & \square \text { High School }\end{array}$

$\square$ Less than high School

$\square$ Other. (Which?)

8. What is your training area? (please mark your response)

$\begin{array}{lll}\square \text { Economics/Management } & \square \text { Auditing } \\ \square \text { Accounting } & \square \text { Public Administration } & \square \text { Other. (Which?) }\end{array}$

9. What is your age? (please mark you response)

$<25$ years

$25-35$ years

$\square 36-45$ years

$46-55$ years

$\square>55$ years 
MRJIAM

210

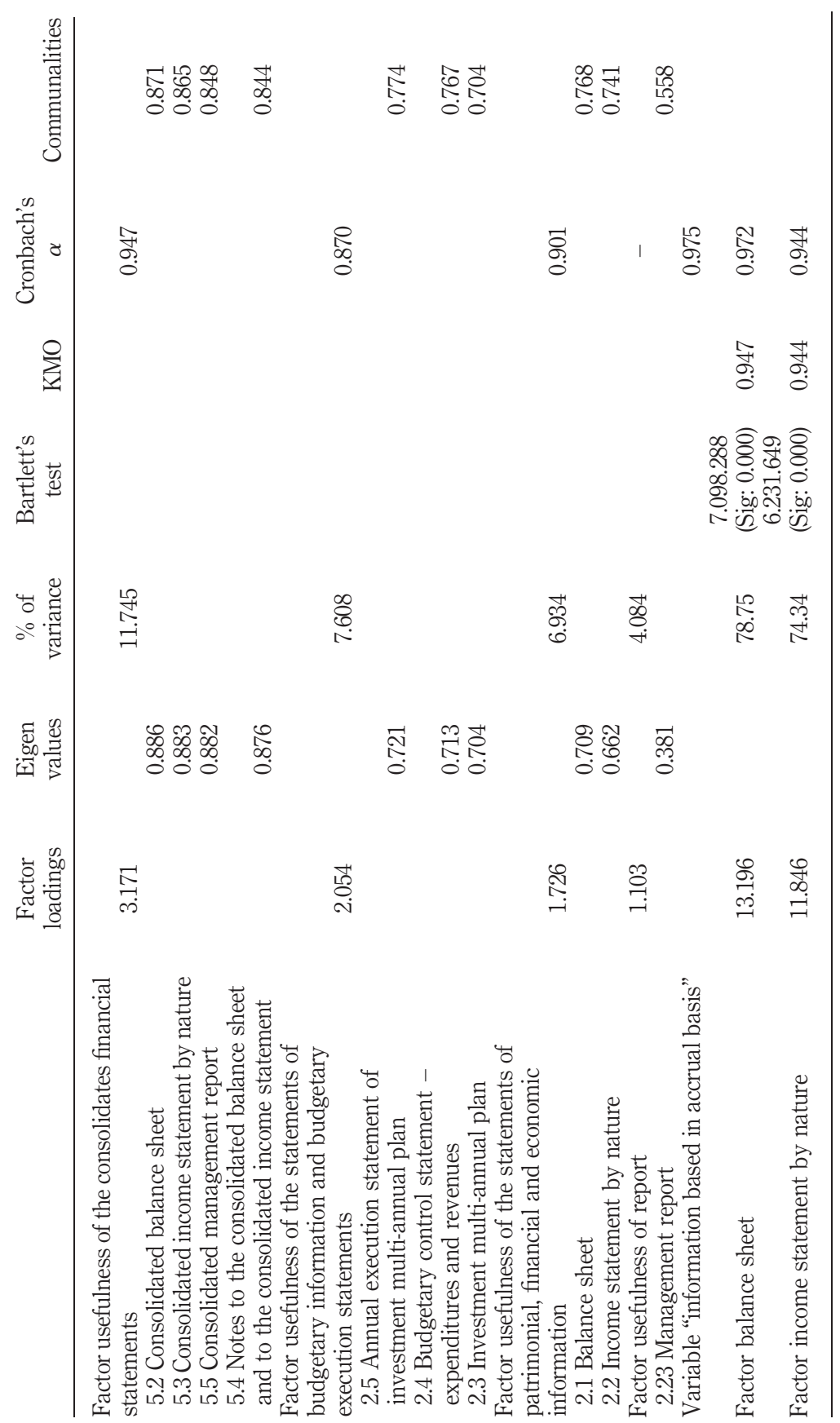




\section{About the authors}

Sónia Paula S. Nogueira is a teaching assistant in Public Sector Accounting and Public Audit at the School of Public Management, Communication and Tourism at the Polytechnic Institute of Bragança - Portugal, for undergraduate degrees. Her research has always reflected interest in public sector accounting, particularly in the local government area. Her main recent investigation touches issues such as usefulness of financial reporting in the context of decision making of Portuguese local administration. She was awarded her Master's degree in Management and Accounting by the Economics and Business School, University of Minho, Portugal, in 2006 and sufficiency researcher in Accounting and Business Organization, by the Business and Economic Sciences School, Autonomous University of Madrid, Spain, in 2010. Currently, she is a doctoral student in Accounting and Business Organization Doctoral, by Economic and Business Sciences School, Universidad Autónoma of Madrid, Spain, in the public accounting field. She has been the author of national and international communications on public sector accounting, specifically on local government accounting, such as the communications delivered at the VIII Accounting and Auditing Congress, Portugal in 2011, XVII Portuguese Association Congress for Regional Development, Portugal in 2011, X International Congress of Costs, France in 2007 and II Catalan Congress of Accounting and Management, Spain in 2007. She is also a co-author of the book Balanced Scorecard Applied to Public Administration (2007, Lisbon, Portugal: Publisher Team). She has received the award "Luiz Chaves de Almeida" - 2010, for the research "Usefulness of financial information municipal for internal users' decision making: the case of the municipality of Bragança”. Sónia Paula S. Nogueira is the corresponding author and can be contacted at: sonia@ipb.pt

Susana Margarida F. Jorge has taught at the Faculty of Economics of the University of Coimbra (FEUC) since 1996. She became Assistant Professor in 2003 and was awarded a permanent position in 2008. Currently lecturing on public sector accounting and financial accounting, both at undergraduate and postgraduate levels, her research interests focus on public sector accounting and management, especially on the local government area. She was awarded her first degree in Business Management (FEUC, Portugal) in 1994, MSc in Business Management - Corporate Finance (Economics and Business School, University of Minho, Portugal) in 1998, and $\mathrm{PhD}$ in Accounting and Finance - Local Government Accounting (Birmingham Business School, University of Birmingham, UK) in 2003. She is a member of the Scientific Board of the international network CIGAR - Comparative International Governmental Accounting Research (www.cigar-network.net) and affiliated member of the research center NEAPP - Núcleo de Estudos em Administração e Políticas Públicas (Research Centre for Public Policy and Administration) - Economics and Business School, University of Minho, Portugal (research centre acknowledged by the Portuguese Foundation for Science and Technology - FCT, and classified as "Excellent"). She has been the author of several national and international publications and communications on local government accounting and management, including editing the book Implementing Reforms in Public Sector Accounting, published by the Coimbra University Press in 2008. She was Chair of the 11th CIGAR Biennial Conference "Implementing reforms in Public Sector Accounting: problems, changes and results", held at FEUC in June 2007, and has been co-chairing [with Jan van Helden] the CIGAR (biennial) $\mathrm{PhD}$ Symposium since then. She is also the editor of the CIGAR Newsletter (per trimester), since April 2010. Among other Portuguese and Brazilian journals, she is a member of the editorial board of Contabilidade e Gestão - Revista Cientifica da OTOC (Accounting and Management, Scientific Journal of the Portuguese Order of Certified Accountants). She was researcher in the project "A Eficiência no Uso dos Recursos Públicos e a Qualidade da Decisão Municipal Portuguesa" (Efficiency in the use of public resources and the quality of municipal decision making) - funded by FCT (POCTI/CPO/58391/2004).

Mercedes Cervera Oliver has an undergraduate degree in Economics and Management from Universidad de Zaragoza and a PhD in Management from Universidad Autónoma de Madrid.

\section{The usefulness of financial reporting}

211 
MRJIAM

11,2

212
She has been a Professor of Cost Accounting in the Accounting Department of Facultad de Ciencias Económicas y Empresariales of Universidad Autónoma de Madrid, since 1991/1992. She was an Associate Professor of the Accounting and Finance Department of Universidad de Zaragoza in 1989-1991, cooperates with the CEF (Centro de Estudios Financieros) since 1992, Instituto de Administración y Dirección de Empresas (IADE) and program CITIUS (Fundación Universidad Empresa) of Universidad Autónoma de Madrid. She is the author of several accounting articles, particularly in Contabilidady Tributación and Partida Doble and participated in several research projects in IADE, as well as several national and international conferences of accounting. 